\title{
On the sub-micron aerosol size distribution in a coastal-rural site at El Arenosillo Station (SW - Spain)
}

\author{
M. Sorribas ${ }^{1, *}$, B. A. de la Morena ${ }^{1}$, B. Wehner ${ }^{2}$, J. F. López ${ }^{1}$, N. Prats ${ }^{3, * *}$, S. Mogo ${ }^{4}$, A. Wiedensohler ${ }^{2}$, and \\ V. E. Cachorro \\ ${ }^{1}$ El Arenosillo - Atmospheric Sounding Station, Atmospheric Research and Instrumentation Branch, INTA, \\ Mazagón-Huelva, Spain \\ ${ }^{2}$ Leibniz-Institute for Tropospheric Research, Leipzig, Germany \\ ${ }^{3}$ Atmospheric Optics Group, University of Valladolid, Valladolid, Spain \\ ${ }^{4}$ Department of Physics, University of Beira Interior, Covilhã, Portugal \\ *now at: Andalusian Center for Environmental Research (CEAMA), University of Granada, Spain \\ ** now at: Meteorological State Agency, AEMET, Canary Island, Spain
}

Received: 14 January 2011 - Published in Atmos. Chem. Phys. Discuss.: 2 February 2011

Revised: 6 October 2011 - Accepted: 6 October 2011 - Published: 10 November 2011

\begin{abstract}
This study focuses on the analysis of the submicron aerosol characteristics at El Arenosillo Station, a rural and coastal environment in South-western Spain between 1 August 2004 and 31 July 2006 (594 days). The mean total concentration $\left(N_{\mathrm{T}}\right)$ was $8660 \mathrm{~cm}^{-3}$ and the mean concentrations in the nucleation $\left(N_{\mathrm{NUC}}\right)$, Aitken $\left(N_{\mathrm{AIT}}\right)$ and accumulation $\left(N_{\mathrm{ACC}}\right)$ particle size ranges were $2830 \mathrm{~cm}^{-3}, 4110 \mathrm{~cm}^{-3}$ and $1720 \mathrm{~cm}^{-3}$, respectively. Median size distribution was characterised by a single-modal fit, with a geometric diameter, median number concentration and geometric standard deviation of $60 \mathrm{~nm}, 5390 \mathrm{~cm}^{-3}$ and 2.31 , respectively. Characterisation of primary emissions, secondary particle formation, changes to meteorology and long-term transport has been necessary to understand the seasonal and annual variability of the total and modal particle concentration. Number concentrations exhibited a diurnal pattern with maximum concentrations around noon. This was governed by the concentrations of the nucleation and Aitken modes during the warm seasons and only by the nucleation mode during the cold seasons. Similar monthly mean total concentrations were observed throughout the year due to a clear inverse variation between the monthly mean $N_{\mathrm{NUC}}$ and $N_{\mathrm{ACC}}$. It was related to the impact of desert dust and continental air masses on the monthly mean particle levels. These air masses were associated with high values of $N_{\mathrm{ACC}}$ which suppressed the new particle formation (decreasing $N_{\mathrm{NUC}}$ ). Each day was
\end{abstract}

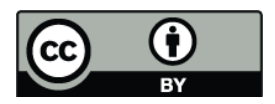

Correspondence to: M. Sorribas (sorribasmm@inta.es) classified according to a land breeze flow or a synoptic pattern influence. The median size distribution for desert dust and continental aerosol was dominated by the Aitken and accumulation modes, and marine air masses were dominated by the nucleation and Aitken modes. Particles moved offshore due to the land breeze and had an impact on the particle burden at noon, especially when the wind was blowing from the NW sector in the morning during summer time. This increased $N_{\mathrm{NUC}}$ and $N_{\mathrm{AIT}}$ by factors of 3.1 and 2.4, respectively. Nucleation events with the typical "banana" shape were characterised by a mean particle nucleation rate of $0.74 \mathrm{~cm}^{-3} \mathrm{~s}^{-1}$, a mean growth rate of $1.96 \mathrm{~nm} \mathrm{~h}^{-1}$ and a mean total duration of $9.25 \mathrm{~h}$ (starting at 10:55 GMT and ending at 20:10 GMT). They were observed for 48 days. Other nucleation events were identified as those produced by the emissions from the industrial areas located at a distance of $35 \mathrm{~km}$. They were observed for 42 days. Both nucleation events were strongly linked to the marine air mass origin.

\section{Introduction}

Sub-micron particles in the atmosphere (with diameters smaller than $1 \mu \mathrm{m}$ ) origin from both natural and anthropogenic sources. Primary aerosol is directly emitted (seasalt, desert dust, biomass and fossil fuel burning) or secondary aerosol can be the result of chemical reactions by gas-to-particle processes (secondary organic aerosols, sulfate and nitrate). The importance of the secondary particle formation on a global scale is uncertain although, it may make a

Published by Copernicus Publications on behalf of the European Geosciences Union. 
significant contribution to particle concentration. Moreover, it has been shown that the seasonal total concentration cycle observed is better simulated by including the new particle formation mechanism than by increasing the number of emissions from primary sources (Spracklen et al., 2010). Sub-micron aerosol is highly variable around the world and plays an important role in global and regional climate. According to Charlson and Wigley (1994), the concentration of natural aerosol has roughly remained the same since the industrial revolution, but human activity has increased the concentration of the anthropogenic aerosol. The report of the Intergovernmental Panel of Climate Change (Solomon et al., 2007) claims that the effect of the anthropogenic aerosol on climate change is still uncertain: therefore, more research is needed to improve our understanding. The direct effect of aerosol particles on climate is related to the absorption and scattering of solar radiation. The ratio of scattering to extinction coefficients describes the single scattering albedo and, thus, the influence of the aerosols on the radiative balance of the atmosphere (Takemura et al., 2002). The scattering properties of the aerosol can be measured, but can also be calculated theoretically from particle size distribution and the Mie Theory. The comparison of observed and calculated scattering allows closure studies (Kleefeld et al., 2002; Shen et al., 2011). The indirect forcing by aerosol is defined as the process by which aerosols modify the Earth's energy balance by the modulation of the cloud albedo and cloud amount. The ability of an aerosol particle to act as cloud condensation nucleus (CCN) depends on its size (Charlson et al., 1987). Sub-micron particles comprise of the largest sources of CCN (Yum et al., 2007; Spracklen et al., 2008).

Sub-micron particles have a wide range of atmospheric lifetimes (from some seconds to days) and can, therefore, be studied by means of the processes of formation, growth and removal of the particles in the atmosphere (Birmili and Wiedensohler, 2000; Boy and Kulmala, 2002; Kulmala et al., 2004; Hamed et al., 2007; Jeong et al., 2010). They can also be studied by their transport flow patterns from the aerosol sources to the sampling site (Birmili et al., 2001; Van Dingenen et al., 2005; Wehner et al., 2008; Shen et al., 2011). During the last decade, the particle number size distribution has been measured in many places around the world (Heintzenberg et al., 2000; Kulmala et al., 2004) under different atmospheric conditions. These measurements have been taken on different platforms (ground, ships or aircraft) and during sampling over short periods, such as campaigns (Antilla et al., 2005; Van Dingenen et al., 2005; Mahajan et al., 2011), or during long-term monitoring programmes (Birmili et al., 2003; Tunved et al., 2003; Venzac et al., 2009).

In this context, a continuous background aerosol monitoring has been performed since 1996 at "El Arenosillo" - Atmospheric Sounding Station, which is located on the southwest coast of Spain and in a rural area. Initially, the efforts at the site were focused on the characterisation of the aerosol optical properties by means of remote-sensing methods, using spectro-radiometer and photometric measurements, (Vergaz et al., 2005; Toledano et al., 2007a, b; Cachorro et al., 2008; Prats et al., 2008). In order to quantify the contribution of the tropospheric aerosol on columnar aerosol (Córdoba-Jabonero et al., 2011), in-situ monitoring of particle number size distribution commenced in 2004.

The objective of this paper is to report the first description of the sub-micron particle number size distribution and, within this framework, to improve the knowledge about the origin, levels and behaviour of sub-micron aerosol sources in a rural and coastal area at mid-latitudes, such as the background environment of Doñana National Park. Other aerosol properties, such as $\mathrm{PM}_{10}$ and $\mathrm{PM}_{2.5}$ mass concentrations, have been widely analysed in this area (Querol et al., 2004, 2008; Sánchez de la Campa et al., 2009), but studies about the long-term particle number size variability in southern Europe and especially in the Iberian Peninsula, clearly relevant to climate sciences, are lacking. This need of information is remedied by the present study.

Primary emissions and meteorology, transport and deposition changes are not sufficient to explain the observed particle levels at sites worldwide (Spracklen et al., 2010) and, thus, particle also needs to be taken into account (assuming binary (Kulmala et al., 1998) or ternary (Korhonen et al., 1999) homogeneous nucleation or an empirical particle formation mechanism (Kulmala et al., 2006)). Thus, this study contains the following sections: the area of study, the sampling station and the aerosol instrumentation, including its intercomparison with a GAW (Global Atmospheric Watch) standard, are described in Sect. 2. The results and discussion are given in Sect. 3. In Sects. 3.1, 3.2 and 3.3, a statistical analysis of the size distribution over the course of two years by means of the diurnal, seasonal and annual cycles of the total and modal concentration is shown. A comparison with particle concentrations at other stations is also presented. In Sect. 3.4, a day's segregation by means of regional and synoptic-scale patterns was performed according to the surface data of wind speed and direction. This categorization was supplemented with an identification of the different types of new particle formation episodes. Section 3.5 shows a classification of the air mass origin on the basis of cluster analysis, to determine the influence of long-range transport aerosol sources on the particle number size distribution. In Sect. 3.6, the results of the size distribution analysis according to sea-land breeze processes are presented and discussed. And finally, in Sect. 3.7, the new particle formation events are illustrated in terms of the particle source.

\section{Site, measurements and methods}

\subsection{Sampling station site}

"El Arenosillo" - Atmospheric Sounding Station is an investigation platform for several topics on atmospheric sciences 
(aerosols, gaseous pollutants, visible and UV radiation stratospheric ozone, ionosphere layer, etc). One of the main research subjects at this station is the in situ and remote sensing of aerosol: from particulate mass levels (gravimetric) and chemical composition (Sánchez de la Campa et al., 2009), super- and sub-micrometer particle number size distributions (Sorribas, 2008) and integrating scattering and absorbing coefficients (Mogo et al., 2005, 2010), to physical and radiative properties of columnar aerosol (Toledano et al., 2007a). The station is also equipped with different instrumentation for monitoring other atmospheric parameters, such as stratospheric ozone and UV solar radiation, to study their effects on biological ecosystems. It is now also capable of monitoring concentration of gaseous pollutants $\left(\mathrm{O}_{3}, \mathrm{NO}_{2}\right.$ and $\left.\mathrm{NO}_{\mathrm{x}}\right)$ and meteorological parameters.

The observatory is located in the province of Huelva $\left(37.1^{\circ} \mathrm{N}, 6.7^{\circ} \mathrm{W}, 40 \mathrm{~m}\right.$ a.s.l.), on the coast of the Atlantic Ocean and close to the Mediterranean Sea and the North African coast (Fig. 1). It is situated in a protected rural environment (Doñana National Park), which covers an extensive area with a homogeneous Mediterranean pine forest, and a coastal area to the south-west where the Atlantic Ocean is less than $1 \mathrm{~km}$ away. The nearest population is a small village, named Mazagón, which is about $8 \mathrm{~km}$ to the northwest. The closest large population is the City of Huelva (160000 inhabitants), $35 \mathrm{~km}$ to the northwest. Emissions from industrial areas around Huelva could contribute to the background levels at the sampling site during northwest winds.

The main aerosol types present at El Arenosillo Station are coastal marine, continental and desert dust. Air mass back-trajectories from 2000 to 2004, with starting heights of $500 \mathrm{~m}$ a.s.l., were used to identify the aerosol source regions. The trajectories showed that $44 \%$ of air masses are coastal marine, while $38 \%$ are continental aerosol air masses and $18 \%$ are desert dust air masses (Toledano, 2005). Desert dust events are more frequent during February and March and during summer months (Toledano et al., 2007b; Prats et al., 2008; Córdoba-Jabonero et al., 2011).

A wind rose for the period (1 August 2004-31 July 2006) is presented in Fig. 1. The winds were most common from the NE and the SW, indicating that air came perpendicular to the Atlantic coast line. The influence of a recirculation of coastal air such as the sea-land breeze is more common in spring and summer time with an occurrence probability of $30 \%$ in May and a maximum of $70 \%$ in August (Adame et al., 2008). Because the sampling area is very flat, they can be considered as a mesoscale phenomenon. Winds from Huelva City (NW) and its surroundings were observed at a lower occurrence.

An evaluation of the main meteorological characteristics showed that the average ambient temperature oscillated between $26^{\circ} \mathrm{C}$ in August and $12{ }^{\circ} \mathrm{C}$ in January (annual average $=19^{\circ} \mathrm{C}$ ). Wind speed ranged from less than $2.5 \mathrm{~ms}^{-1}$ in June to as high as $3.2 \mathrm{~ms}^{-1}$ in December (annual average $=3 \mathrm{~ms}^{-1}$ ) (Adame et al., 2008).

\subsection{Scanning mobility particle spectrometer intercomparison}

The dry ambient sub-micron particle number size distribution was monitored with a Scanning Mobility Particle Sizer (SMPS) particle spectrometer (Knutson and Whitby, 1975). The SMPS (TSI Model 3936) is made up of a differential particle size classifier (TSI Model 3080, Electrostatic Classifier), a Condensation Particle Counter (TSI Model 3022A) for particle detection and the AIM software (version 4.3, TSI INC., St. Paul., MN, USA) for data reduction and analysis of the SMPS output. The polydisperse aerosol flow was $0.31 \mathrm{~min}^{-1}$ and the sheath flow was $31 \mathrm{~min}^{-1}$, which was dried with silica gel in a closed loop.

In order to assess the quality of the measurements, an intercomparison of our system was carried out at the World Calibration Centre for Physical Aerosol Research (WCCAP) at Institut für Troposphärenforschung (IfT) in Leipzig (Germany). IfT is endorsed by the WMO within the framework of the GAW programme and it has designed a calibration programme to maintain and compare aerosol instrumentation, such as the SMPS. Limitations of our system were assessed during an intercomparison campaign held at the IfT from 8 to 10 December 2003. Some instrumental restrictions are the low efficiency for measuring the nucleation and Aitken modes due to the losses in the Differential Mobility Analyzer (DMA) inlet (Birmili et al., 1997) and in the Condensation Particle Counter (CPC) (Su et al., 1990).

The instrument of the IfT was a Differential Mobility Particle Sizer (DMPS), which is capable of measuring the particle mobility diameter in the range of 7-400 nm. In the Electrostatic Classifier, the particles pass through a $\mathrm{Kr}-85$ Bipolar Charger and though a short-DMA with $18 \mathrm{~cm}$ central electrode. The CPC Model used was the 3010 of TSI. The aerosol and sheath flows were $1.01 \mathrm{~min}^{-1}$ and $101 \mathrm{~min}^{-1}$, respectively.

Both of the spectrometers were connected to the same sampling system of atmospheric aerosol, therefore, both instruments characterised the same air volume and the losses in the inlet and transport lines were the same. The measurements were carried out simultaneously every four minutes.

The correction factor (CF) was calculated using the ratio of the same hourly averages of particle size distribution given by the SMPS - El Arenosillo and the DMPS-IfT. This CF allowed us to account for the losses that appeared in the SMPSEl Arenosillo, assuming that the DMPS-IfT is the standard instrument. For diameters smaller than $70 \mathrm{~nm}$, a decrease in SMPS efficiency was observed, with a value of $50 \%$ at $20 \mathrm{~nm}$. The CF was 1 for particle sizes larger than $70 \mathrm{~nm}$. Using this CF a good consistency between both systems was observed. 


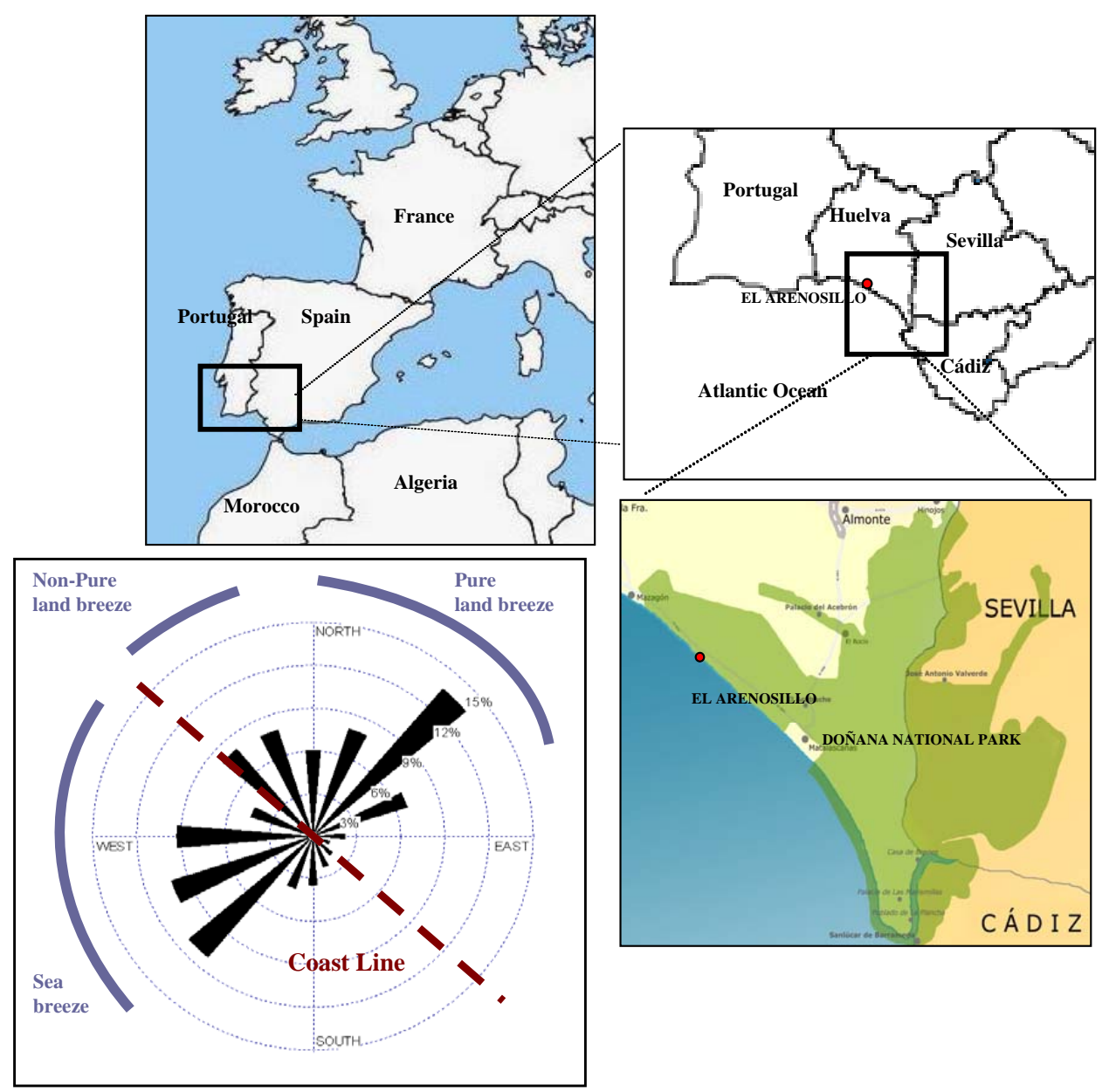

Fig. 1. Map of the Iberian Peninsula highlighting the location of El Arenosillo Station. The wind rose from 1 August 2004 to 31 July 2006 and the coastal line are also shown, indicating with an arc on the wind rose the wind directions for non-pure land, pure land and sea breeze patterns.

\subsection{Dataset}

The surface aerosol measurements were carried out at El Arenosillo Station. The inlet was placed at $3 \mathrm{~m}$ above the forest and about $8 \mathrm{~m}$ above ground level. The aerosol sampling was conducted according to Sheridan et al. (2001) with a flow rate of $3301 \mathrm{~min}^{-1}$ and Reynolds Number $R e=9100$, using a vertical stainless steel tube $(48 \mathrm{~cm}$ inner diameter and $550 \mathrm{~cm}$ length). This outer tube was placed concentrically around the inner tube $(1 \mathrm{~cm}$ inner diameter and $120 \mathrm{~cm}$ length), which transported the sampled aerosol into the laboratory with a broad curve into the flow splitter. In this inner tube, the flow rate was $13.31 \mathrm{~min}^{-1}$ and $R e=1820$. A conductive flexible tube with $0.6 \mathrm{~cm}$ inner diameter transported the aerosol flow from the flow splitter to the SMPS instrument. The sampling system efficiency calculated according to Willeke and Baron (1993), ranged from $85 \%$ for $16.5 \mathrm{~nm}$ particles to $94 \%$ for $604 \mathrm{~nm}$ particles. Sampling losses were corrected for data processing presented in Sect. 3 .
The sub-micron particle number size distributions were measured continuously with a time resolution of $10 \mathrm{~min}$ from 1 August 2004 to 31 July 2006. During this period there was one longer gap, from 25 July to 11 October 2005, due to some instrument failure. The SMPS was operational for 594 days $(81 \%)$ and its maintenance was performed according to the standard procedures. The accuracy of DMA size selection was tested with polystyrene latex spheres (PLS) and the diameters that were obtained were within $2 \%$ of those expected.

All of the spectra were checked and inaccurate measurements were removed. Rain processes have a great effect on particle scavenging and were not considered in this study (about $2 \%$ of the entire dataset). More than 75000 valid size distributions were obtained. The temporal coverage of data (in percentages) during the period of study was about $(81 \pm 15) \%$ of the valid size distributions per month. In this study, particle number size distributions were assumed to have a three modal structure: a nucleation mode (14-30) nm, 
Table 1. Statistics for total and modal concentrations of several moments of the size distribution for 1-h year data series. $\tilde{N}$ is the arithmetic mean concentration, $\tilde{n}$ is the geometric mean concentration, $\sigma$ is the standard deviation and $\mu_{\mathrm{x}}$ values are the $x$ th percentiles.

\begin{tabular}{llrrrrrrrr}
\hline & Unit & $\tilde{N}$ & $\tilde{n}$ & $\sigma$ & $\mu_{05}$ & $\mu_{16}$ & $\mu_{50}$ & $\mu_{84}$ & $\mu_{95}$ \\
\hline$N_{\mathrm{T}}$ & $\mathrm{cm}^{-3}$ & 8660 & 7046 & 6740 & 2310 & 4050 & 7090 & 12810 & 19960 \\
$N_{\text {NUC }}$ & $\mathrm{cm}^{-3}$ & 2830 & 1470 & 4510 & 210 & 495 & 1470 & 4725 & 10520 \\
$N_{\text {AIT }}$ & $\mathrm{cm}^{-3}$ & 4110 & 3240 & 3220 & 1000 & 1710 & 3260 & 6280 & 10100 \\
$N_{\text {ACC }}$ & $\mathrm{cm}^{-3}$ & 1720 & 1355 & 1120 & 340 & 635 & 1530 & 2750 & 3730 \\
\hline$S_{\mathrm{T}}$ & $\mu \mathrm{m}^{2} \mathrm{~cm}^{-3}$ & 245 & 200 & 140 & 55 & 105 & 220 & 370 & 486 \\
$S_{\text {NUC }}$ & $\mu \mathrm{m}^{2} \mathrm{~cm}^{-3}$ & 5 & 3 & 7 & 0 & 1 & 3 & 8 & 17 \\
$S_{\text {AIT }}$ & $\mu \mathrm{m}^{2} \mathrm{~cm}^{-3}$ & 50 & 40 & 30 & 10 & 20 & 40 & 10 & 110 \\
$S_{\text {ACC }}$ & $\mu \mathrm{m}^{2} \mathrm{~cm}^{-3}$ & 190 & 150 & 130 & 40 & 70 & 170 & 300 & 410 \\
\hline$V_{\mathrm{T}}$ & $\mu \mathrm{m}^{3} \mathrm{~cm}^{-3}$ & 9 & 7 & 6 & 2 & 3 & 8 & 14 & 19 \\
$V_{\text {NUC }}$ & $\mu \mathrm{m}^{3} \mathrm{~cm}^{-3}$ & 0 & 0 & 0 & 0 & 0 & 0 & 0 & 0 \\
$V_{\text {AIT }}$ & $\mu \mathrm{m}^{3} \mathrm{~cm}^{-3}$ & 1 & 0 & 0 & 0 & 0 & 0 & 1 & 1 \\
$V_{\text {ACC }}$ & $\mu \mathrm{m}^{3} \mathrm{~cm}^{-3}$ & 8 & 6 & 6 & 1 & 3 & 7 & 13 & 18 \\
\hline
\end{tabular}

an Aitken mode (30-100) nm and an accumulation mode (100-673) nm. The term "ultrafine size range" was used to define particles with a diameter below $100 \mathrm{~nm}$ (nucleation plus Aitken modes). The term "Mode-i" was used to describe each mode $(i=1,2, \ldots)$ of the size distribution function when it was log-normal fitted. The expressions "singlemodal fit", "bi- modal fit" and "tri- modal fit" were used to describe the lognormal fitting algorithms.

Meteorological parameters (temperature, relative humidity, pressure and wind speed and direction) were obtained $0.5 \mathrm{~km}$ southwest of the sampling site.

\section{Results and discussion}

\subsection{General characteristics of the particle size distribution}

\subsubsection{Mode descriptions}

To study the particle number size distribution, statistics for the total aerosol and for each of the modes are presented in Table 1 . The arithmetic mean value $(\tilde{N})$ for total particle concentration $\left(N_{\mathrm{T}}\right)$ was $(8660 \pm 6740) \mathrm{cm}^{-3}$ (" \pm " indicates standard deviation $(\sigma)$ in this study). The median value $\left(\mu_{50}\right)$ (with $\mu_{16}-\mu_{84}$ percentiles) of 7090 (4050-12 810) $\mathrm{cm}^{-3}$ indicates that the most frequent values were smaller than the mean total concentration. Figure 2 shows how $N_{\mathrm{T}}$ was distributed around a mean value of $8660 \mathrm{~cm}^{-3}$ with the highest frequency at $(6000-7500) \mathrm{cm}^{-3}$ and only $1 \%$ of total concentration was above $24000 \mathrm{~cm}^{-3}$.

For modal concentrations, the arithmetic mean values $(\tilde{N})$ were $2830 \mathrm{~cm}^{-3}, 4110 \mathrm{~cm}^{-3}$ and $1720 \mathrm{~cm}^{-3}$ for the nucleation $\left(N_{\mathrm{NUC}}\right)$, Aitken $\left(N_{\mathrm{AIT}}\right)$ and accumulation $\left(N_{\mathrm{ACC}}\right)$ modes, respectively (Table 1$)$. The standard deviation $(\sigma)$ of

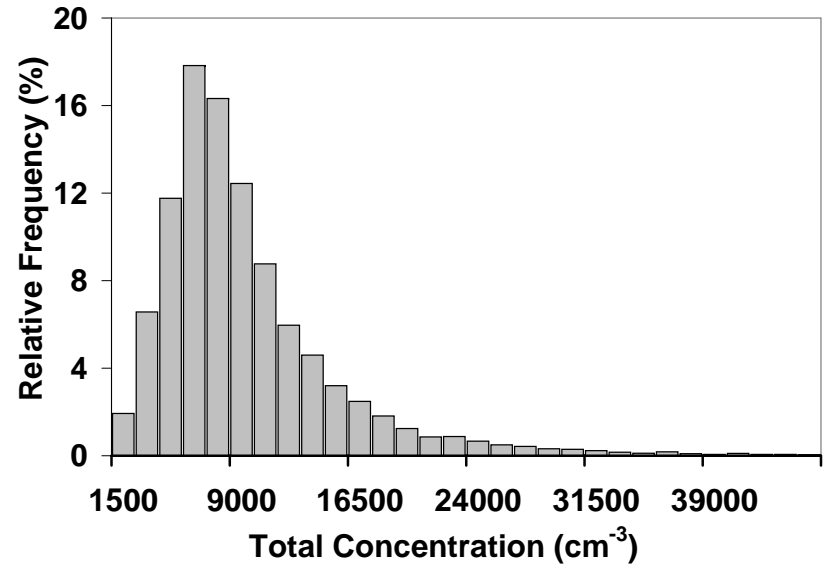

Fig. 2. The relative occurrence frequencies of total particle concentrations of 1-h data for the two-year period under study.

$N_{\mathrm{NUC}}$ presented a variation of $160 \%$, indicating that $N_{\mathrm{NUC}}$ varied greatly around the mean with some high particle levels which cause a shift of the $\sigma$ towards higher values than the mean. The $\sigma$ for $N_{\mathrm{AIT}}$ and $N_{\mathrm{ACC}}$ were greater than $75 \%$. The median modal concentrations $\left(\mu_{50}\right)$ (with $\mu_{16}-\mu_{84}$ percentiles) were $1470(495-4725) \mathrm{cm}^{-3}$ for $N_{\mathrm{NUC}}, 3260$ (1710-6280) $\mathrm{cm}^{-3}$ for $N_{\mathrm{AIT}}$ and $1530(635-2750) \mathrm{cm}^{-3}$ for $N_{\text {ACC. }}$.

The mean total particle surface area $\left(S_{\mathrm{T}}\right)$ and volume $\left(V_{\mathrm{T}}\right)$ concentrations were $(245 \pm 140) \mu \mathrm{m}^{2} \mathrm{~cm}^{-3}$ and $(9 \pm 6) \mu \mathrm{m}^{3} \mathrm{~cm}^{-3}$, respectively, and the median total concentrations (with $\mu_{16}-\mu_{84}$ percentiles) were 220 (105370) $\mu \mathrm{m}^{2} \mathrm{~cm}^{-3}$ and $8(3-14) \mu \mathrm{m}^{3} \mathrm{~cm}^{-3}$ (Table 1).

To study the relationship between different particle size ranges, the linear correlation coefficients $(R)$ between hourly 
mean $N_{\mathrm{NUC}} \& N_{\mathrm{AIT}}(R=0.4)$, hourly mean $N_{\mathrm{AIT}} \& N_{\mathrm{ACC}}$ $(R=0.4)$ and hourly mean $N_{\mathrm{NUC}} \& N_{\mathrm{ACC}}(R=0.1)$ were calculated. As expected, concentrations for $N_{\mathrm{NUC}} \& N_{\mathrm{AIT}}$ and $N_{\text {AIT }} \& N_{\text {ACC }}$ were statistically (although only weakly) dependent on each other in terms of hourly means by processes such as nucleation, condensation and coagulation.

\subsubsection{Comparison with total and modal concentrations at other stations}

Comparisons with other size distributions measured at sites of similar latitudes were made based on previous studies. These investigations included observations (Asmi et al., 2011) and comparisons between measurements and results obtained from global aerosol models (Spracklen et al., 2010) of total particle number concentrations, which show diurnal, weekly and seasonal variability at different stations around the world. Using the study of Spracklen et al. (2010) as a reference, measurements made at mid-latitude coastal locations showed mean total particle concentrations between $1000 \mathrm{~cm}^{-3}$ and $2000 \mathrm{~cm}^{-3}$, while greater concentrations of $3000 \mathrm{~cm}^{-3}$ were observed at Mace Head station (west coast of Ireland). Given that El Arenosillo station is at a midlatitude coastal site, it may be expected that mean particle levels are similar to those concentrations at other coastal areas. However, the influence of continental, desert dust and anthropogenic aerosol sources increases the coastal background particle level at El Arenosillo Station. The mean total concentration was, therefore, closer to the observations of continental boundary sites than to levels of the marine boundary layer.

This assumption is also corroborated by the study of Asmi et al. (2011). The median concentration of $\left(N_{\mathrm{AIT}}+N_{\mathrm{ACC}}\right)$ observed at El Arenosillo Station is the second highest value measured in Central Europe, behind Ispra Station with $7188 \mathrm{~cm}^{-3}$ and ahead of Cabauw and K-Puszta Stations with $5126 \mathrm{~cm}^{-3}$ and $4648 \mathrm{~cm}^{-3}$, respectively. $N_{\mathrm{NUC}}$ at El Arenosillo Station is greater than $N_{\mathrm{NUC}}$ at Ispra (Rodríguez et al., 2005) and Melpitz Stations (Birmili et al., 2003). Therefore, the total and modal particle concentration at El Arenosillo was closer to the levels found in rural areas located in Central Europe, than to those found in the coastal rural sites of the mid-latitudes.

The technique for fitting the annual median size distribution applied by Asmi et al. (2011) has been used in our work to compare the fit function over the two-year period at El Arenosillo with those fitting parameters as obtained at other European sites. This technique applies lognormal fitting algorithms, single- and bi-modal fits for particle sizes greater than $20 \mathrm{~nm}$, since the size range of (30-100) nm is of particular interest as these are the particles that act as CCN. The size distributions of these size range show (slightly skewed) lognormal distributions. The modal parameters for both fits are shown in Table 2. The single-mode fit had a geometric mean diameter $\left(D_{\mathrm{g}}\right)$, a number concentration $(N)$ and a geomet- ric standard deviation $\left(\sigma_{\mathrm{g}}\right)$ of $60 \mathrm{~nm}, 5390 \mathrm{~cm}^{-3}$ and 2.31 , respectively. These modal parameters are more similar than to those obtained at other European Stations like Waldhof (Germany), Ispra (Italy) and Cabauw (the Netherlands). The bi-modal fit for El Arenosillo presents two modes strongly overlapping similar to the annual median size distribution function for Ispra and Cabauw. The goodness of fit function value was characterised by the correlation coefficient $\left(R^{2}\right)$, resulting that both fitting procedures show very high $R$. The annual median size distribution can, therefore, be fitted by using a single-mode fit which is corroborated by the annual median size distribution function of the most of the stations in Asmi et al. (2011). Thus, even though the real size distributions might be more complex (i.e., can be separated into more modes), the representation of a single-mode that quantifies the important particle range at different station is also useful. Using this methodology, models could be tested by reproducing the size distributions for different stations.

\subsection{Monthly, seasonal and annual total and modal concentrations}

Figure 3 shows the monthly means of the total and modal particle number concentrations, which were calculated using daily averages. The standard deviation is also indicated (grey vertical lines), showing the wide range of values of the daily mean concentrations.

A seasonal behaviour of the total particle concentration was not observed at El Arenosillo (Fig. 3a), showing a different feature amongst other European rural sites which showed maxima during summer (Birmili et al., 2001; Tunved et al., 2003) or during autumn-winter (Rodríguez et al., 2005). By contrast, other compounds at El Arenosillo Station, such as the tropospheric ozone, exhibit an increase in concentration from winter ( $56 \mu \mathrm{g} \mathrm{m}^{-3}$ in January) to summer $\left(85 \mu \mathrm{g} \mathrm{m}^{-3}\right.$ in July) (Adame et al., 2010a). The absence of seasonal variation of the total particle concentration was produced by a clear inverse variation between $N_{\mathrm{NUC}}$ and $N_{\mathrm{ACC}}$ (Figs. $3 \mathrm{~b}$ and 3d). Thus, Period A (January-April 2005) evinced an increase/decrease of $N_{\mathrm{NUC}} / N_{\mathrm{ACC}}$ and Period B (April-June 2005) showed the opposite behaviour.

Figure 4 shows how the monthly means of $N_{\mathrm{NUC}}$ vary with the monthly means of $N_{\mathrm{ACC}}$ (red line) and $N_{\mathrm{AIT}}$ (black line) over a two-year period. The correlation $N_{\mathrm{ACC}} \& N_{\mathrm{NUC}}$ allows us to conclude that every decrease/increase in the accumulation mode of about $0.4 \mathrm{~cm}^{-3}$ (slope value given directly on the graph) relates to an increase/decrease in the nucleation mode of $1 \mathrm{~cm}^{-3}$. If the correlation coefficients $(R)$ of the monthly means of $N_{\mathrm{ACC}} \& N_{\mathrm{NUC}}$ and $N_{\mathrm{AIT}} \& N_{\mathrm{NUC}}$ (with values 0.7 and 0.5 , respectively) are compared to those calculated from the hourly means (Sect. 3.1), an influence of the different time scales on the correlations is found as $R$ was higher when long-term scales were used. Thus, hourly means were statistically independent, but monthly means were related. 
Table 2. Modal fit parameters for median size distribution of the two-year period at El Arenosillo considered single- and bi-modal fits for particle sizes greater than $20 \mathrm{~nm} . D_{\mathrm{g}, i}, N_{i}$ and $\sigma_{\mathrm{I}}$ represent the geometric diameter, median number concentration and geometric standard deviation, respectively. The goodness of fit function value was characterised by the correlation coefficient $\left(R^{2}\right)$.

\begin{tabular}{cccc|ccccccc}
\hline \multicolumn{3}{c|}{ Single-modal fit } & \multicolumn{8}{c}{ Bi-modal fit } \\
\hline \multirow{2}{*}{$D_{\mathrm{g} \mathrm{nm}}$} & $N \mathrm{~cm}^{-3}$ & $\sigma_{\mathrm{g}}$ & $R^{2}$ & $D_{\mathrm{g}, 1} \mathrm{~nm}$ & $N_{1} \mathrm{~cm}^{-3}$ & $\sigma_{\mathrm{g}, 1}$ & $D_{\mathrm{g}, 2} \mathrm{~nm}$ & $N_{2} \mathrm{~cm}^{-3}$ & $\sigma_{\mathrm{g}, 2}$ & $R^{2}$ \\
\hline 60 & 5910 & 2.31 & 0.99 & 37 & 3820 & 2.50 & 85 & 1950 & 1.85 & 1.00 \\
\hline
\end{tabular}
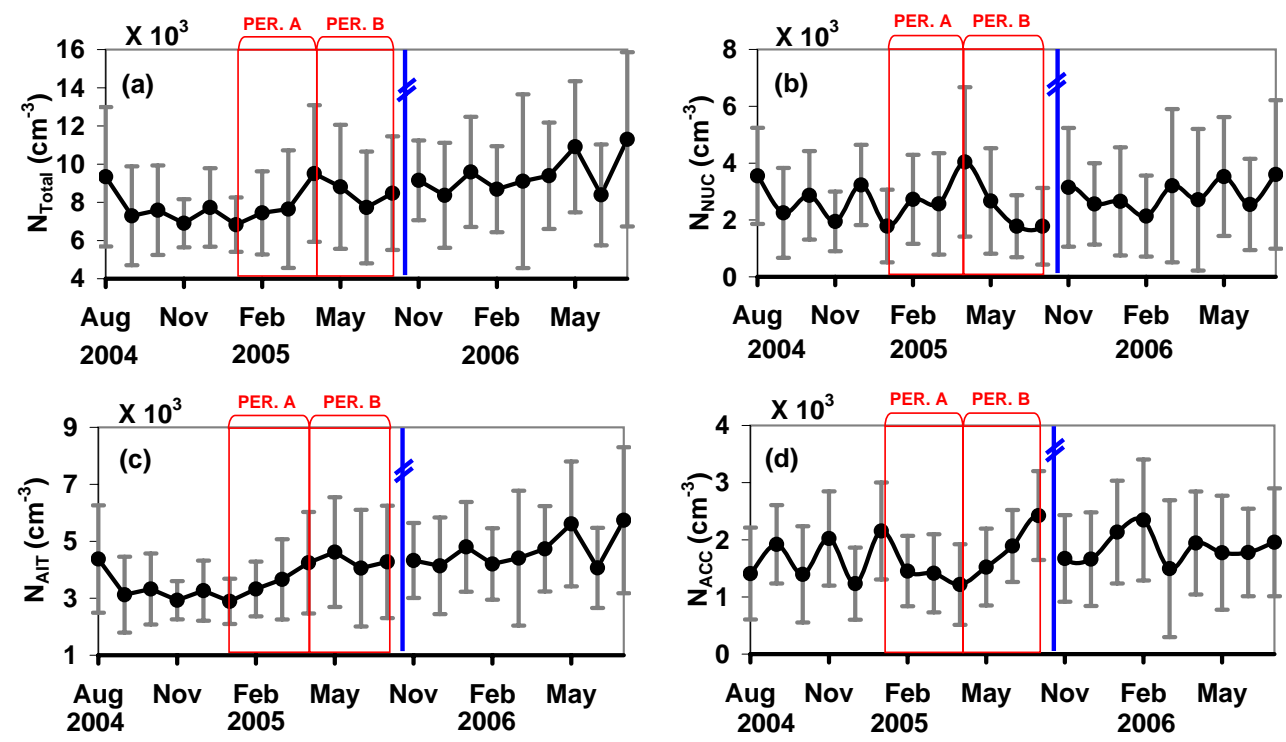

Fig. 3. Annual cycle with monthly mean levels for (a) $N_{\mathrm{T}}$, (b) $N_{\mathrm{NUC}}$, (c) $N_{\mathrm{AIT}}$ and (d) $N_{\mathrm{ACC}}$. The standard deviation (grey vertical lines) is also shown, as well as two periods are selected (red lines) to better understanding of the monthly trend: Period A (January-April) 2005 and Period B (April-July) 2005. Blue lines indicate the break of the annual cycle due to the longest data gap.

The high monthly mean values of $N_{\mathrm{NUC}}$, shown in Fig. 4 , can be related to the number of days per month when new particle formation events occurred. This process could be promoted by a reduction of $N_{\mathrm{ACC}}$ due to fewer desert dust and continental air masses arriving at El Arenosillo. The low values of $N_{\text {ACC }}$ were related to small surface area concentrations which could favour the homogeneous nucleation processes (increasing $N_{\mathrm{NUC}}$ ) of pre-existing precursor gases. The high monthly means of $N_{\mathrm{ACC}}$ shown in Fig. 4 could be due to the presence of large particles from desert dust and continental air mass and from an increase in atmospheric stagnation. This resulted in aerosol aging and, therefore, in an increase of $N_{\mathrm{ACC}}$. Both processes are present over the Iberian Peninsula during spring-summer (Toledano et al., 2007b; Querol et al., 2008). The high values of $N_{\text {ACC }}$ were associated with large surface area concentrations which favoured the condensation of gases onto pre-existing particles and suppressed the new particle formation (decreasing $N_{\text {NUC }}$ ). Previous studies have also shown a reduction of $N_{\text {NUC }}$ within dusty regions of up to $20 \%$ through this mech- anism (Manktelow et al., 2010). Thus, the importance of the particle formation events in determining the existence and the absence of the seasonal particle concentration cycle is evident. This assumption has also been used in models to simulate the particle concentration (Spracklen et al., 2010).

The differences in the monthly mean concentrations, observed during similar time periods during the two-years of study, are striking. A comparison of particle levels in April 2005 and April 2006 shows that $N_{\text {NUC }}$ and $N_{\text {AIT }}$ were lower by a factor of 1.5 and higher by a factor of 1.6 during the latter time periods. These differences are related to the desert dust episodes, as shown below. Toledano et al. (2007b) did not report April as a month influenced by desert dust episodes, on the basis of photometric measurements. In the present study, a mean aerosol optical depth (AOD - $440 \mathrm{~nm}$ ) of 0.15 and a mean Ångström exponent $(\alpha)$ of 1.09 were observed, (AERONET Level 2.0) in April 2005, and in April 2006 , these mean values were 0.25 and 0.76 , respectively (AERONET Level 1.5 - no data in Level 2.0 were recorded). Taking into account these mean values and those obtained by 


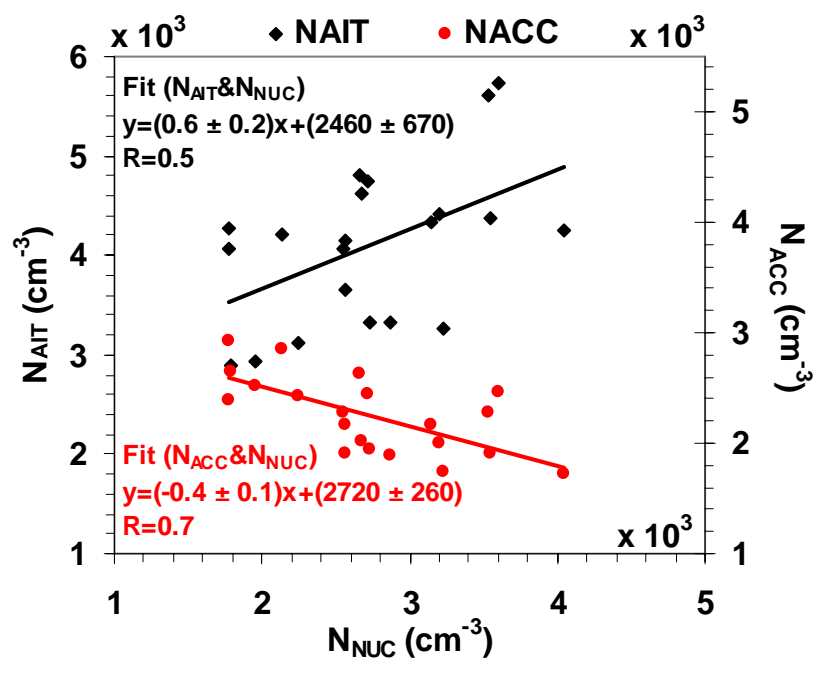

Fig. 4. The linear fits between the monthly mean $N_{\mathrm{AIT}}$ and $N_{\mathrm{NUC}}$ (black line) and between the monthly mean $N_{\mathrm{ACC}}$ and $N_{\mathrm{NUC}}$ (red line). The coefficient of correlation and the standard deviation of the slope and the intercept are also shown for both linear fits.

the inventory of African desert dust events over El Arenosillo (Toledano et al., 2007b), the number of observations of desert dust aerosols is higher in April 2006 than in April 2005. In addition, this will be corroborated by the back-trajectory analysis at $500 \mathrm{~m}$ presented in Sect. 3.7.

\subsection{Diurnal patterns of the modal concentrations}

Figure 5 shows the daily mean cycles per season for the total and modal concentrations which were calculated from the daily mean cycles per month. The aerosol size distributions were dominated by the nucleation and Aitken modes during spring-summer times with the maximum hourly mean for the diurnal cycle of $N_{\mathrm{NUC}} / N_{\mathrm{AIT}}$ at $6750 / 5590 \mathrm{~cm}^{-3}$ and $7290 / 6670 \mathrm{~cm}^{-3}$, respectively. During autumn and winter, the diurnal cycle of the aerosol size distributions was dominated primarily by the nucleation mode with the maximum hourly mean of about $5000 \mathrm{~cm}^{-3}$. The maximum $N_{\mathrm{NUC}}$ was reached at 11:00 GMT and 10:00 GMT during spring and summer times, respectively, and for $N_{\mathrm{AIT}}$ at 11:00 GMT for both time periods. By contrast, during the colder autumn and winter the maxima for $N_{\mathrm{NUC}}$ were reached at 14:00 GMT and 13:00 GMT, respectively, and for $N_{\mathrm{AIT}}$ during the night. On the other hand, the diurnal cycle of $N_{\mathrm{ACC}}$ was not observed because the accumulation mode is composed mainly by long-lived particles (Rodríguez et al., 2005; Shen et al., 2011).

There was an increase in concentration for all particle modes during afternoons of summer months (Fig. 5). We propose that the VOC concentrations were greater at night than during the day, in spite of lower emissions, due to the shallower and more stable nocturnal boundary layer (Ieda et

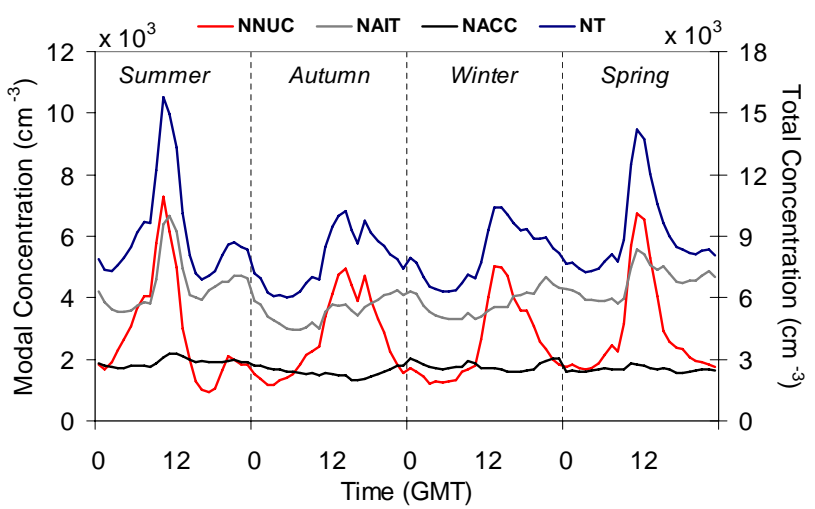

Fig. 5. Daily mean cycles of the total and nucleation, Aitken and accumulation mode concentrations per season, July-September (summer), October-December (autumn), January-March (winter) and April-June (spring).

al., 2006). This may induce particle growth by coagulation of small particles and by condensation of volatile organic components on pre-existing particles (Kulmala et al., 2001; Rodríguez et al., 2005), and subsequent increases in $N_{\mathrm{NUC}}$ and $N_{\mathrm{AIT}}$ in the late afternoon.

The minimum hourly mean levels for $N_{\mathrm{T}}$ during the cold months were $15 \%$ lower than during the warm months. This difference may be due to the meteorological scenarios that cause atmospheric stagnation during the warm months, characterised by the lack of renewal of the air masses. During these episodes, the particle transport to rural areas takes place through a regional atmospheric circulation (e.g. a breeze phenomenon), thereby increasing the particle and gas concentrations in rural areas (Gangoiti et al., 2002; Querol et al., 2008; Adame et al., 2010b).

\subsection{Day's segregation by means of regional and synoptic-scale patterns}

If there is no strong synoptic forcing, the coastal areas are influenced by mesoscale processes due to the diurnal heating and cooling differences between the land and sea. In a region like El Arenosillo, in which a wide area has an altitude close to sea level, the mesoscale flow determines the regional atmospheric conditions which affect the recirculation of aerosol particles emitted by local and long-range transport sources. With the aim to present the main properties of the particle size distribution, each day was initially classified on the basis of the sea-land breeze phenomenon (Adame et al., 2010a). The 594 days of the data set were separated into 104 days $(18 \%)$ under the influence of a recirculation of coastal air and into 490 days (82\%) with synoptic-scale patterns. The classification scheme is shown in Fig. 6. The percentages in brackets refer to the 594 days of the data set.

The long-term monitoring carried out during the 490 days with no influence of the sea-land breeze pattern (Fig. 6) 


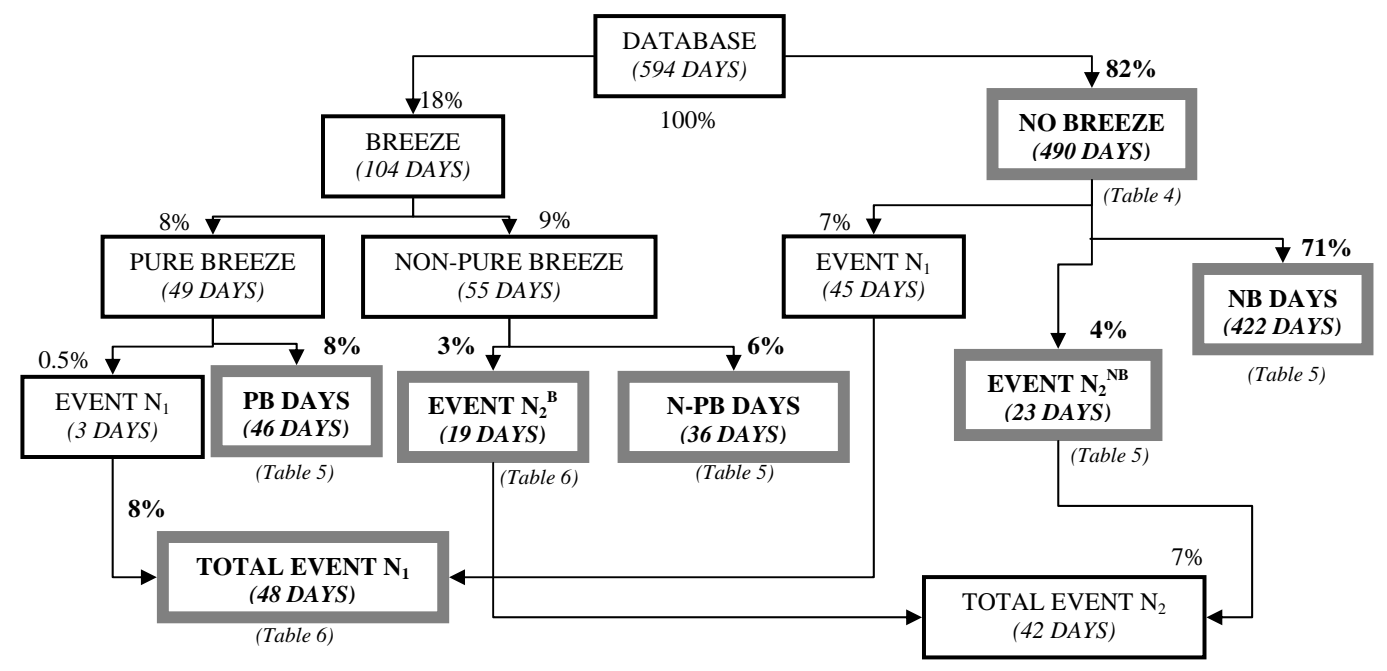

Fig. 6. Representative days' segregation by means of sea-land breezes (pure and non-pure) days and nucleation events $\left(N_{1}\right.$ and $\left.N_{2}\right)$. Tables containing the modal parameters of the median size distribution function for each classification are also indicated.

allows the investigation of the particle size distribution in terms of air mass type (Birmili et al., 2001; Tunved et al., 2003; Shen et al., 2011). An analysis of the flow patterns and the influence of these synoptic-scale patterns on the particle size distribution will be presented in Sect. 3.5.

Adame et al. (2010a) identified the existence of two sealand breeze patterns, called "pure-breeze" and "non-pure breeze", at El Arenosillo. In our dataset, the 104 days under the influence of the sea-land breeze can be segregated into 49 days $(8 \%)$ of the pure breeze type and into 55 days $(9 \%)$ of the non-pure breeze type. The diurnal variation of the particle size distribution and of the wind direction allowed for the identification of two types of high particle number concentration events: the first related to the sea-land breeze days and the accumulation of the particle in the wind flow, and the second related to the new particle formation by nucleation processes. The nucleation events are shown in Fig. 6 as Events $N_{1}$ and $N_{2}$. If the days with Events $N_{1}$ and $N_{2}$ are removed from the classification of non-breeze and breeze days, 46 days $(8 \%)$ were representative of the pure breeze pattern (PB days), 36 days (6\%) of non-pure breeze pattern (N-PB days) and 422 days (71\%) of no breeze pattern (NB days). The properties of the size distribution for NB, PB and N-PB days will be discussed in Sect. 3.6, and the main characteristics of Events $N_{1}$ and $N_{2}$ will be presented in Sect. 3.7.

Figure 7 illustrates the monthly relative frequencies of days under non-pure and pure breeze and synoptic-scale flows together with the number of such days per month during the studied period. This classification has been performed, by applying the days' segregation described above and allows us to evaluate the impact of the regional circulation processes, the long-range transport air masses and the nucleation events over the monthly mean size distributions.

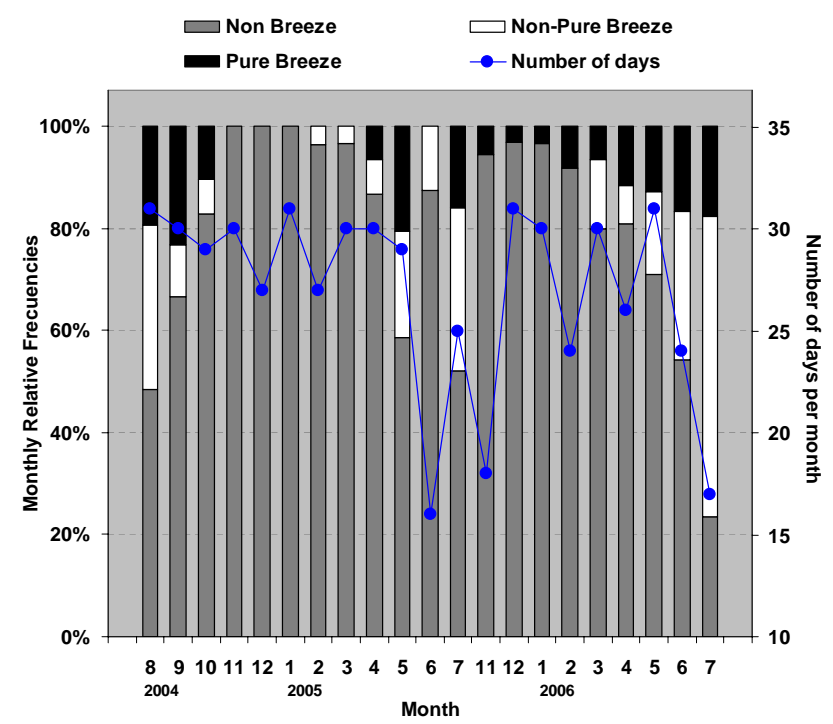

Fig. 7. Frequency of monthly occurrence as percentages of nonpure breeze and pure breeze and non-breeze days (left axis), and the number of days per month (right axis), during the two-year period under study.

\subsection{Size distribution in relation to air masses}

In this section, the variation in the particle size distributions is analysed based on their different air mass histories. To represent the atmospheric flows arriving at different heights over a sampling site, the back-trajectories have been widely used in previous investigations (Venzac et al., 2009; Córdoba-Jabonero et al., 2011; Lozano et al., 2011). The back-trajectories used in our study were calculated using 
the HYSPLIT (Hybrid Single Particle Lagrangian Integrated Trajectory) model (Draxler and Hess, 1998). 3-D-backtrajectories were evaluated using the vertical wind method and the 120-h duration was selected to appropriately account for synoptic-scale processes (Kivekäs et al., 2009; Hondula et al., 2009).

The influence of the air mass origin on column-integrated optical properties of aerosol over El Arenosillo from 2000 to 2004 was investigated by Toledano et al. (2009). In that study, the mean back-trajectories at 500, 1500 and $3000 \mathrm{~m}$ (hereinafter referred to as centroids) were evaluated by cluster analysis, using a non-hierarchical method based on the Euclidean distance between the trajectories in two dimensions (latitude and longitude). To select the optimal number of clusters, the variation of the total root-mean-square deviation (rmsd) versus the number of clusters was evaluated. Given that the selected threshold is arbitrary, a $7 \%$ change in the rmsd determined the optimal number of clusters. In our work, the same methodology for back-trajectory classification will be used.

\subsubsection{Main characteristics of the atmospheric flows}

With the aim to represent the long-range aerosol transport in the lower atmosphere appropriately and to determine a representative height of the air mass back-trajectory endpoints, a set of 4-day back-trajectories at 100, 500 and $900 \mathrm{~m}$ were calculated over El Arenosillo Station. Taking into account the seasonality of air mass types, the back-trajectories were calculated for a representative month of each season (January, April, July and October) from August 2004 to July 2006, at 00:00, 06:00, 12:00 and 18:00 GMT. Thus, each set of backtrajectories at 100, 500 and $900 \mathrm{~m}$ was represented by seven clusters. Each height of the back-trajectory endpoints had a similar set of mean atmospheric flows during the previous 120-h over El Arenosillo. The similarities found among the aerosol sources of the three atmospheric levels allow us to conclude that the aerosol properties among the different levels are homogeneous. Following this conclusion and the detailed study of the air masses at $500 \mathrm{~m}$ over El Arenosillo discussed by Toledano et al. (2009), which shows similar atmospheric flows to those of our analysis, the heights of the $500 \mathrm{~m}$ endpoints were assumed to be the most representative for in-situ measurements.

Once the representative height levels are selected, 4-day air mass back-trajectories at $500 \mathrm{~m}$ (at 00:00, 06:00, 12:00 and 18:00 GMT) were computed daily during the 490 days without regional circulation. They were classified using the seven clusters evaluated by Toledano et al. (2009) at this altitude, which are shown in Fig. 8. The difference between the clusters observed in Fig. 8 and those clusters evaluated during our analysis of the most representative height for in-situ measurements (see previous paragraph) was only the temporal coverage used to calculate the back-trajectories. The temporal coverage was higher for the mean back-trajectories

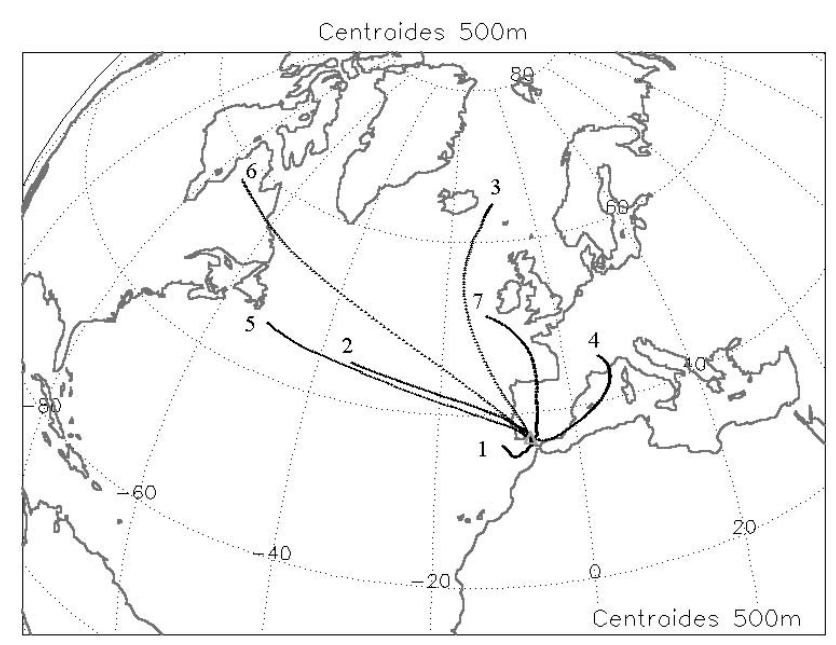

Fig. 8. Centroids of the cluster classification at $500 \mathrm{~m}$ identified according to the back-trajectory analysis using the HYSPLIT model (Toledano et al., 2009).

presented in Fig. 8 and then, the corresponding seven clusters were selected to classify the back-trajectories.

The monthly frequency of the classification results is presented in Table 3. The main atmospheric transport regime was of oceanic origin which is represented by clusters 2 , 3,5 and 6 , which together had an occurrence frequency of $42 \%$. The maritime westerly flow pathway from the Atlantic Ocean was characterised by clusters 2 and 5, which are distinguished from each other only in terms of the transportation speed of the air masses. The cluster is longer when the wind speed is greater: therefore, cluster 5 was associated with the faster-moving maritime trajectories from western Atlantic. Aerosol of marine, north-westerly origin from the Atlantic and Arctic Oceans were found in cluster 6 and cluster 3, respectively. Finally, cluster 1 included the regional and North African air masses with $20 \%$ of the data, while continental flow pathways from the Iberian Peninsula and those from central and northern Europe, were represented by cluster 7 ( $14 \%$ of the cases) and cluster 4 (24\% of the cases), respectively.

A high variability can be observed in seasonal patterns shown in Table 3. The transport of desert dust aerosol from North Africa (cluster 1) was most frequent during spring and summer months. While marine air masses from the western sector (clusters 2 and 5) were most common during summer months, flows from the north-westerly sector (clusters 3 and 6) occurred during the winter months. The continental air masses arriving at El Arenosillo from central and northern Europe were less frequent during summer-autumn months and those for the Iberian Peninsula during spring and summer months. 
Table 3. Monthly relative frequencies in percentages of air masses at $500 \mathrm{~m}$ according to the clustering algorithm during the 498 days under synoptic-scale pattern. Centroids of the cluster classification at $500 \mathrm{~m}$ are identified in Fig. 9.

\begin{tabular}{|c|c|c|c|c|c|c|c|}
\hline \multirow[b]{2}{*}{2004} & \multirow{2}{*}{$\frac{\text { Desert Dust }}{\text { Cluster } 1}$} & \multicolumn{2}{|c|}{ Western marine } & \multicolumn{2}{|c|}{ North western marine } & \multicolumn{2}{|c|}{ Continental } \\
\hline & & Cluster 2 & Cluster 5 & Cluster 6 & Cluster 3 & Cluster 4 & Cluster 7 \\
\hline August & 15 & 40 & 20 & 3 & 0 & 20 & 2 \\
\hline September & 35 & 20 & 3 & 1 & 0 & 13 & 28 \\
\hline October & 17 & 26 & 10 & 3 & 19 & 18 & 7 \\
\hline November & 26 & 3 & 2 & 5 & 6 & 33 & 25 \\
\hline December & 12 & 8 & 10 & 17 & 10 & 33 & 10 \\
\hline \multicolumn{8}{|l|}{2005} \\
\hline January & 19 & 11 & 8 & 4 & 8 & 31 & 19 \\
\hline February & 4 & 6 & 0 & 4 & 16 & 37 & 33 \\
\hline March & 24 & 9 & 20 & 5 & 6 & 33 & 3 \\
\hline April & 5 & 28 & 15 & 10 & 15 & 20 & 7 \\
\hline May & 18 & 25 & 13 & 0 & 11 & 25 & 8 \\
\hline June & 12 & 18 & 0 & 0 & 2 & 38 & 30 \\
\hline July & 7 & 32 & 24 & 0 & 7 & 22 & 8 \\
\hline November & 23 & 1 & 8 & 7 & 18 & 11 & 32 \\
\hline December & 18 & 18 & 7 & 16 & 2 & 10 & 29 \\
\hline \multicolumn{8}{|l|}{2006} \\
\hline January & 21 & 0 & 4 & 23 & 14 & 22 & 16 \\
\hline February & 22 & 7 & 2 & 17 & 22 & 28 & 2 \\
\hline March & 16 & 14 & 29 & 10 & 27 & 0 & 4 \\
\hline April & 44 & 18 & 12 & 9 & 3 & 13 & 1 \\
\hline May & 31 & 1 & 10 & 17 & 1 & 35 & 5 \\
\hline June & 31 & 0 & 0 & 0 & 15 & 44 & 10 \\
\hline July & 43 & 13 & 22 & 0 & 13 & 9 & 0 \\
\hline \multicolumn{8}{|l|}{ Mean Annual } \\
\hline Period 2004 & 21 & 17 & 8 & 7 & 8 & 25 & 15 \\
\hline Period 2005 & 15 & 16 & 10 & 5 & 9 & 26 & 19 \\
\hline Period 2006 & 28 & 7 & 11 & 13 & 14 & 21 & 6 \\
\hline Period 2004-2006 & 20 & 14 & 10 & 8 & 10 & 24 & 14 \\
\hline
\end{tabular}

\subsubsection{Median size distribution in terms of the atmospheric flows}

To evaluate the median particle number size distribution per cluster the following methodology was used. As being representative for each day, four size distributions were calculated by finding the median of the hourly size distributions, which are within a 6-h interval centred on the arrival time of the air masses at El Arenosillo. For example, the median size distribution for the air mass arriving at 06:00 GMT was calculated using the measured size distributions from 03:00 GMT to 08:00 GMT, which was then included in the group that contains the data of the cluster assigned to 06:00 GMT. The same data process was applied to the 12:00 GMT, 18:00 GMT and 00:00 GMT time slots. Finally, the median data value in each cluster group was evaluated. Figure $9 \mathrm{a}-\mathrm{g}$ shows the median size distribution averaged over all days for each of the seven clusters and the 16th and 84th percentiles.
The resulting median size distribution has been log-normal fitted for particles sizes greater than $20 \mathrm{~nm}$ following the fitting procedure by Asmi et al. (2011), and the modal parameters are summarized in Table 4. For clarity, the fitted size distributions are shown in Fig. 10a. The volume-size distribution for each cluster is also presented in Fig. 10b.

Significant differences are found between marine, continental and desert dust air masses. Desert-dust (cluster 1) and the continental air masses (cluster 4 and 7) were characterised by similar median particle number size distributions (Figs. 9 and 10a). Mean total aerosol number concentration was $(7610-7360) \mathrm{cm}^{-3}$, being dominated by Mode2. The median diameters for Modes-1 and -2 were (2223) $\mathrm{nm}$ and (80-84) nm, respectively. Less variability in nucleation and Aitken size ranges for continental and desert dust air masses than for marine air masses (16th and 84th percentiles in Fig. 9) was evident. Mean total surface-area 
Table 4. Median number size distribution log-normal parameters of each cluster. The $D_{\mathrm{g}, i}, N_{i}$ and $\sigma_{\mathrm{I}}$ represent the geometric diameter, median number concentration and geometric standard deviation, respectively. The correlation coefficient $(R)$ between observed and fitted size distributions is also shown. ${ }^{*}$ The median and mean total number concentrations $\left(N_{\mathrm{T}, \text { median }}\right.$ and $N_{\mathrm{T} \text {,mean })}$ are calculated from the measured values instead of the fitted ones.

\begin{tabular}{|c|c|c|c|c|c|c|c|c|c|}
\hline & \multicolumn{3}{|c|}{ Mode-1 } & \multicolumn{3}{|c|}{ Mode-2 } & \multicolumn{2}{|r|}{ Median } & \multirow{2}{*}{$\begin{array}{r}\text { Mean } \\
{ }^{*} N_{\mathrm{T}, \text { mean }} \\
\mathrm{cm}^{-3}\end{array}$} \\
\hline & $\begin{array}{r}D_{\mathrm{g}, 1} \\
\mathrm{~nm}\end{array}$ & $\begin{array}{r}N_{1} \\
\mathrm{~cm}^{-3}\end{array}$ & $\sigma_{\mathrm{g}, 1}$ & $\begin{array}{r}D_{\mathrm{g}, 2} \\
\mathrm{~nm}\end{array}$ & $\begin{array}{r}N_{2} \\
\mathrm{~cm}^{-3}\end{array}$ & $\sigma_{\mathrm{g}, 2}$ & $R^{2}$ & ${ }^{*} N_{\mathrm{T}, \text { median }} \mathrm{cm}^{-3}$ & \\
\hline \multicolumn{10}{|c|}{ Desert dust air mass } \\
\hline Cluster 1 & 22 & 900 & 1.62 & 84 & 5000 & 1.97 & 1.0 & 5740 & 7610 \\
\hline \multicolumn{10}{|c|}{ Western marine air mass } \\
\hline Cluster 2 & 48 & 4150 & 2.00 & 98 & 1330 & 1.90 & 1.0 & 5400 & 8200 \\
\hline Cluster 5 & 37 & 5260 & 1.90 & 108 & 990 & 1.92 & 1.0 & 5860 & 8950 \\
\hline \multicolumn{10}{|c|}{ North western marine air mass } \\
\hline Cluster 3 & 28 & 7990 & 2.50 & 170 & 132 & 1.24 & 1.0 & 6230 & 9310 \\
\hline Cluster 6 & 29 & 8180 & 2.00 & 122 & 1400 & 1.68 & 1.0 & 6020 & 8960 \\
\hline \multicolumn{10}{|c|}{ Continental air mass } \\
\hline Cluster 4 & 22 & 1930 & 1.93 & 84 & 6330 & 1.97 & 1.0 & 6030 & 7620 \\
\hline Cluster 7 & 23 & 2300 & 1.60 & 80 & 6400 & 2.00 & 1.0 & 5780 & 7810 \\
\hline
\end{tabular}
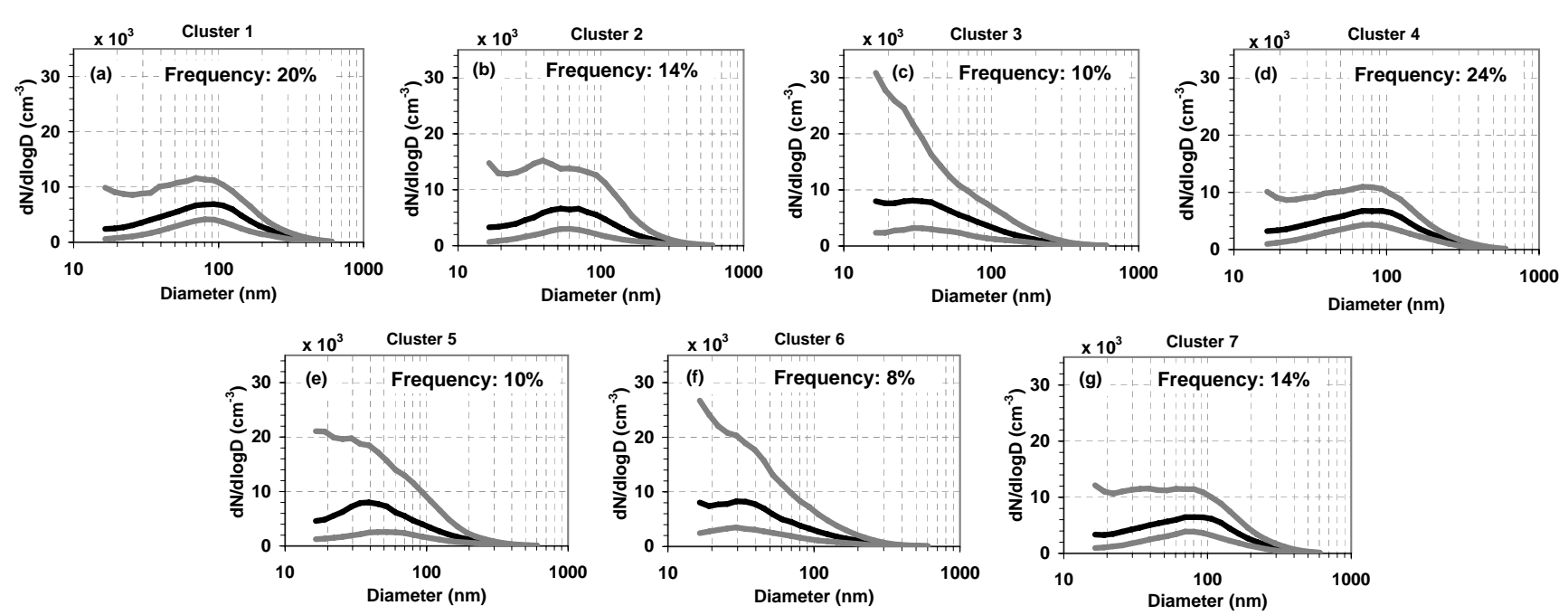

Fig. 9. Median particle number size distribution, averaged over the seven back-trajectory clusters (black) and the 16th and 84th percentiles (grey). The frequency of each cluster over the study period is also shown (Table 3). Cluster 1 is representative of desert-dust, clusters $2,3,5$ and 6 of marine air mass origin and clusters 4 and 7 of continental air mass origin.

and volume concentrations for desert-dust and continental air masses were observed between $270-300 \mu \mathrm{m}^{2} \mathrm{~cm}^{-3}$ and between $10-11.5 \mu \mathrm{m}^{3} \mathrm{~cm}^{-3}$, respectively, with the highest values of both metrics being for desert-dust aerosol (cluster 1).

From the similarities found between the shape of the median size distributions (Fig. 10a), the size distributions representing marine air masses can be divided into those originated from westerly flows (clusters 2 and 5) and those from north-westerly flows (clusters 3 and 6). The main difference between the two groups is that the particle size distribution sampled in air masses arriving from the north-west show a Mode-1 with higher concentration than those air masses from westerly flows.

On the basis of these categories, the median diameters for Modes- 1 and 2 (Table 4) are found at (37-48) nm and (98108) nm, respectively, in westerly flows (clusters 2 and 5), 

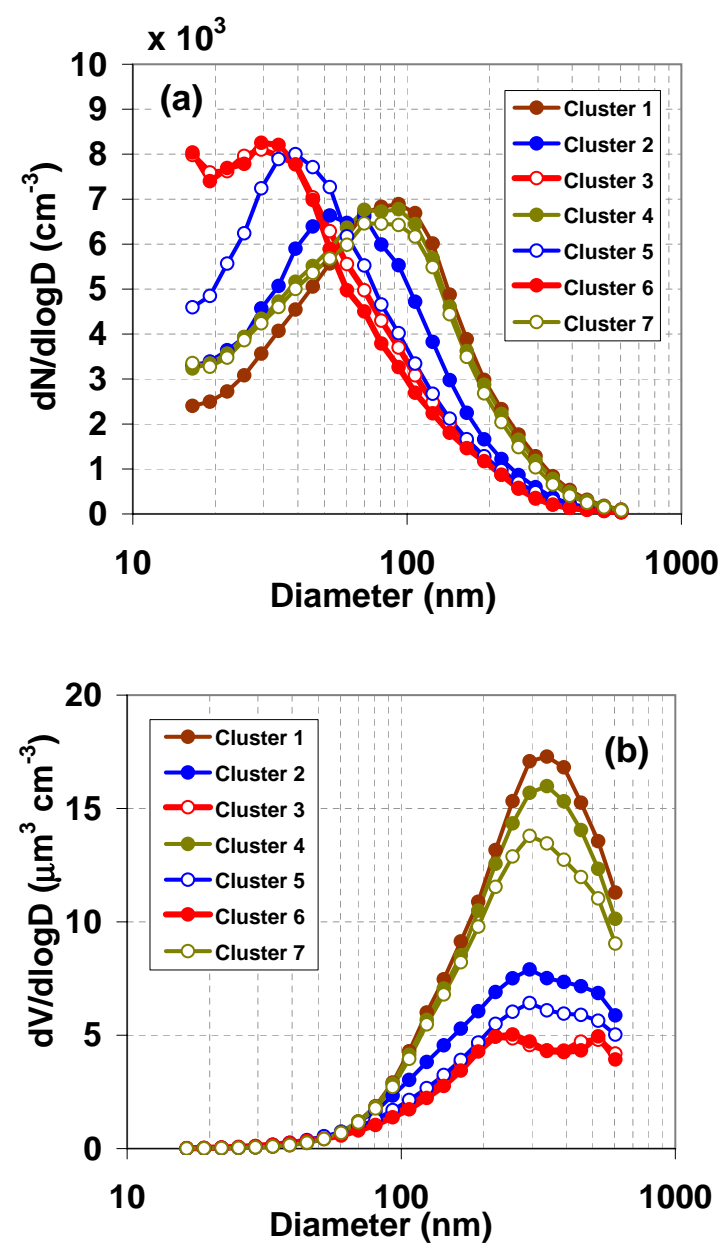

Fig. 10. Median (a) number and (b) volume size distributions per cluster. The colours are related to the flow pathway: Dust - brown (cluster 1), Maritime westerly - blue (clusters 2 and 5), Maritime north-westerly - red (clusters 3 and 6) and Continental - green (clusters 4 and 7).

and at (28-29) nm and (122-170) nm, respectively, in northwesterly flows (clusters 3 and 6). Figures 9c and f shows that the nucleation mode for air masses arriving from the north-west showed the largest variability (16th and 84th percentiles). The mean total number concentrations ranged from 8200 to $9310 \mathrm{~cm}^{-3}$, with the maximum values found in cluster 3. Mean total surface-area and volume concentrations for marine flow pathways ranged from 142 to $208 \mu^{2} \mathrm{~cm}^{-3}$ and from 4.5 to $6.9 \mu \mathrm{m}^{3} \mathrm{~cm}^{-3}$. Concentrations observed in northwesterly flows coming from the Atlantic Ocean (cluster 6) were lower than those observed in the slower-moving maritime trajectories from the western Atlantic (cluster 2).

The impact of the air masses on the particle size distribution is also observed, when comparing the monthly mean concentration for $N_{\mathrm{ACC}}$ (Fig. 3) and the trend of increasing frequencies of continental and desert dust air masses during Period B (see Sect. 3.2), from $32 \%$ to $80 \%$ of days (these values have been evaluated by adding up the individual frequencies shown in Table 3). In addition, the variation between the monthly mean concentrations for $N_{\mathrm{ACC}}$ and $N_{\mathrm{NUC}}$ corroborates the reduction of $N_{\mathrm{NUC}}$ within desert-dust and continental air masses.

\subsection{Size distributions during sea-land breeze days}

The presence of regional recirculation (e.g. the sea-land breeze) is very typical in coastal areas during spring and summer and plays an important role in transporting air pollution from and towards urban areas, (Ma and Lyons, 2003; Sorribas et al., 2007; Pey et al., 2008; Adame et al., 2010a; Wright et al., 2010). Given that El Arenosillo is located in a coastal rural site, the influence of the regional aerosol transport on the background particle level is analysed in this section.

As noted in Sect. 3.4, two types of sea-land breeze have been observed: pure breeze and non-pure breeze. Wind blowing at night from the land towards the sea is called land breeze and it is the result of the nocturnal cooling of the land surface. The wind direction for land breeze flow for pure breeze is mainly from the $\mathrm{NE}\left(0^{\circ}-67^{\circ}\right.$ sector - Doñana National Park and Seville City), whereas it is mainly from the NW $\left(315^{\circ}-337^{\circ}\right.$ sector - Huelva industrial areas) for nonpure breeze (Fig. 1). This local wind produced an accumulation of particles offshore. The wind direction changes at approximately 07:00 GMT and 08:00 GMT for pure breeze and non-pure breeze, respectively, and blows during the day from the sea towards the land (SW sector for both land patterns). This wind is called sea breeze and is the result of the diurnal heating of the land surface. The accumulated offshore particles are then transported back to land, increasing the background levels.

\subsubsection{Median size distribution and diurnal patterns during PB and N-PB days}

Figure 11 shows the median daily particle number size distribution and median diurnal cycle of modal concentrations corresponding to 422 NB-days, 46 PB-days and 36 N-PBdays (Fig. 6). Also represented are the 16th and 84th percentiles, as well as the ratio (mean/median). Moreover, the median size distribution has been log-normal fitted for particle sizes greater than $20 \mathrm{~nm}$ following the fitting procedure used in Asmi et al. (2011). The modal parameters are summarized in Table 5.

While a bi-modal fit was used to calculate the size distribution function for NB and N-PB days, the PB days required a tri-modal fit. This additional mode was observed within the accumulation size range with a geometric median diameter of $300 \mathrm{~nm}$. PB days were characterised by a mean $N_{\mathrm{T}}$ of $8890 \mathrm{~cm}^{-3}$, with a particle concentration for Mode-2 higher than for Mode-1, and the geometric median diameters were $21 \mathrm{~nm}$ and $77 \mathrm{~nm}$ for Modes- 1 and -2, respectively. In 
Table 5. Median number size distribution log-normal parameters of NB, PB and N-PB days. The $D_{\mathrm{g}, i}, N_{i}$ and $\sigma_{\mathrm{I}}$ represent the geometric diameter, median number concentration and the geometric standard deviation, respectively. The correlation coefficient $(R)$ between observed and fitted size distribution is also shown. ${ }^{*}$ The median and mean total number concentrations $\left(N_{\mathrm{T}, \text { median }}\right.$ and $\left.N_{\mathrm{T}, \text { mean }}\right)$ are calculated from the measured values instead of the fitted ones.

\begin{tabular}{|c|c|c|c|c|c|c|c|c|c|c|c|c|}
\hline & \multicolumn{3}{|c|}{ Mode-1 } & \multicolumn{3}{|c|}{ Mode-2 } & \multicolumn{3}{|c|}{ Mode-3 } & \multicolumn{2}{|r|}{ Median } & Mean \\
\hline & $\begin{array}{r}D_{\mathrm{g}, 1} \\
\mathrm{~nm}\end{array}$ & $\begin{array}{r}N_{1} \\
\mathrm{~cm}^{-3}\end{array}$ & $\sigma_{\mathrm{g}, 1}$ & $\begin{array}{r}D_{\mathrm{g}, 2} \\
\mathrm{~nm}\end{array}$ & $\begin{array}{r}N_{2} \\
\mathrm{~cm}^{-3}\end{array}$ & $\sigma_{\mathrm{g}, 2}$ & $\begin{array}{r}D_{\mathrm{g}, 3} \\
\mathrm{~nm}\end{array}$ & $\begin{array}{r}N_{3} \\
\mathrm{~cm}^{-3}\end{array}$ & $\sigma_{\mathrm{g}, 3}$ & $R^{2}$ & $\begin{array}{r}{ }^{*} N_{\mathrm{T}, \text { median }} \\
\mathrm{cm}^{-3}\end{array}$ & $\begin{array}{r}{ }^{*} N_{\mathrm{T}, \text { mean }} \\
\mathrm{cm}^{-3}\end{array}$ \\
\hline NB days & 20 & 2850 & 1.80 & 76 & 4890 & 1.89 & - & - & - & 1.00 & 6900 & 7870 \\
\hline PB days & 21 & 3370 & 1.81 & 77 & 5640 & 1.81 & 300 & 190 & 1.53 & 1.00 & 8100 & 8890 \\
\hline N-PB days & 31 & 10440 & 2.52 & 250 & 110 & 1.42 & - & - & - & 1.00 & 8360 & 9380 \\
\hline
\end{tabular}
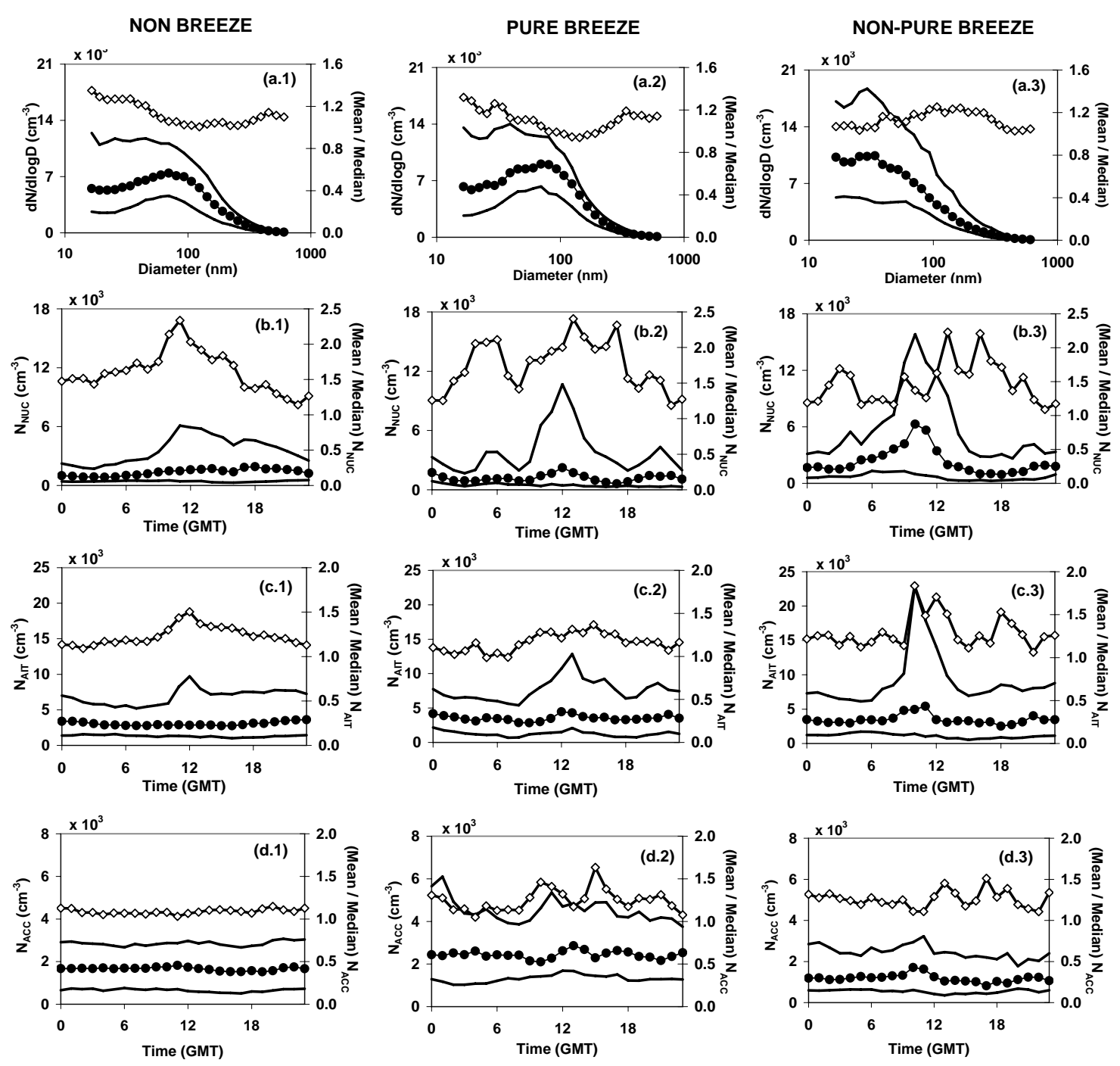

Fig. 11. Median daily (filled symbols), 16th and 84th percentiles (black lines) and the ratio (Mean/Median, open symbols) of particle number size distributions and the modal concentrations for 422 NB-days, 46 PB-days and 36 N-PB-days at El Arenosillo. 
addition, N-PB days reached a mean $N_{\mathrm{T}}$ of $9380 \mathrm{~cm}^{-3}$, with a particle concentration for Mode-1 significantly higher than for Mode-2. The geometric median diameters were $31 \mathrm{~nm}$ and $250 \mathrm{~nm}$ for Modes- 1 and -2 , respectively.

To quantify the effect of each type of breeze on the particle concentration due to the recirculation of air, the mean modal concentration at 04:00 GMT was chosen as a reference of the background particle level. On this basis, the mean maximum concentration of $N_{\mathrm{NUC}}\left(N_{\mathrm{NUCmax}}\right)$ was 2.5 and 3.1 times greater than background concentrations for PB and NPB days, respectively, (Fig. $11 \mathrm{~b} .2$ and 11b.3). The $N_{\text {AITmax }}$, during $\mathrm{PB}$ and N-PB days was 1.6 and 2.4 times greater than background levels (Fig. $11 \mathrm{c} .2$ and 11c.3). Finally, $N_{\mathrm{ACCmax}}$ increased by 1.4 and 1.3 as compared to the background levels for PB and N-PB days (Fig. 11d.2 and 11d.3). Thus, while mean values for modal concentrations are greater than median values for each of the three patterns (NB, N-PB and PB), the difference (shown in Fig. 11 as the ratio of the mean to the median) is larger for $N_{\mathrm{NUC}}$. This again indicates that the highest impact of breeze pattern occurred around noon during N-PB days and mainly influenced $N_{\mathrm{NUC}}$.

During PB days, the diurnal variation of $N_{\mathrm{NUC}}$ showed a minimum (Fig. 11b.2) at 08:00 GMT and a maximum at 20:00 GMT. This was only observed in this scenario. The minimum may be caused by the diurnal fluctuation of the nocturnal microscale inversion height (Hsu, 1988). Nocturnal inversion layers are formed primarily as a result of radiative cooling near a rather uniform land surface. After sunrise, the mixing processes commence and the mixed layer is broken down, increasing the particle dilution and decreasing the particle concentration. The maximum concentration at 20:00 GMT was discussed earlier in Sect. 3.3, in the analysis of the diurnal cycle during the summer months (Fig. 5). During these months, the occurrence of the breeze phenomenon is higher (Fig. 7) due to the reaching of the maximum temperature gradient between land and sea. Figure 11b.2 suggests that the behaviour observed in Fig. 5 only occurs during the PB scenario. Future analysis will be focused on determining the reason for this, and the relationships between meteorological parameters with vertical resolution, by model and experimental studies, gas measurements and aerosol data in the (3-14) nm size range.

Finally, while the maximum concentration at noon for $\mathrm{N}$ PB and PB days was due to the recirculation of accumulated particles produced by the land breeze, the maximum concentration for NB days is attributed to new particle formation events. The difference between the mean size distribution of the nucleation events and the mean total particle concentration of NB days (Fig. 11b.1, 11c.1 and 11d.1) will be explained in Sect. 3.7.

\subsubsection{Breeze patterns based on air mass influences}

The variations in the particle concentrations during days with influence of breeze patterns (PB and N-PB days) are anal- ysed based on their different air mass histories. As Adame et al. (2010a) reported, the pure breeze occurs in the presence of an anticyclonic system with a weak isobaric gradient, caused by high pressure circulation patterns over the Azores Islands and the Western Mediterranean. Therefore, if the clustering classification introduced in Sect. 3.5 is also applied to PB days, $68 \%$ of days (consisting of cluster $1(22 \%)$, cluster 4 $(20 \%)$ and cluster $7(26 \%)$ ) were influenced by continental and desert-dust air masses. The influence of air mass type, with its possible stagnation due to the weak isobaric gradient with the subsequent accumulation and ageing of particles, explains how $N_{\mathrm{ACC}}$ for $\mathrm{PB}$ days is higher than for N-PB days which is supported by the daily pattern of $N_{\mathrm{ACC}}$ shown in Fig. 11d.2. Moreover, the Mode-3 observed in the fitted median size distribution (Table 5) is due to these continental and desert dust aerosols.

By contrast, Adame et al. (2010a) observed that non-pure breeze is characterised by an Atlantic high pressure circulation pattern from the Portuguese coast and/or a low pressure system over the British Isles. If the clustering classification introduced in Sect. 3.5 is applied during N-PB days, $50 \%$ of days (consisting of cluster $2(32 \%)$ and cluster 5 $(18 \%))$ were influenced by maritime westerly flows. The predominance of marine air masses increase the particle levels of Mode-1 and decrease the concentration of Mode-2 (Table 5) by the marine particle transport processes (Heintzenberg et al., 2000). Moreover, these air masses arriving at El Arenosillo from the north-west sector are influenced by local industries whose emissions initiate new particle formation (Sect. 3.7), increasing also the particle concentration of Mode-1 (Table 5).

\subsection{New particle formation events $\left(N_{1}\right.$ and $\left.N_{2}\right)$}

The new particle formation events at El Arenosillo have been classified depending on the wind direction during the hours preceding the nucleation burst. During Event $N_{1}$ the wind direction was mainly from the NE, whereas it was from the NW during Event $N_{2}$. Nucleation events were not observed in the other wind sectors.

\subsubsection{Events $N_{1}$}

Figure 12a.1 and 12a.2 shows the mean diurnal variation of the particle number size distribution, $N_{\mathrm{NUC}}$ and $S_{T}$, and the wind direction for the 48 days (Fig. 6), identified as Event $N_{1}$. The "banana" shape indicates that these events were quite homogeneous in a larger-scale air mass, (Birmili et al., 2003; Kulmala et al., 2004), i.e., the area was not subjected to strong dilution and can be considered as an Eulerian system. New particles were formed and were growing into larger sizes during their transport to El Arenosillo. Freshly nucleated particles contributed to the nucleation mode; their growth by condensation and coagulation increased their sizes and, thus, their later contribution to the Aitken and 

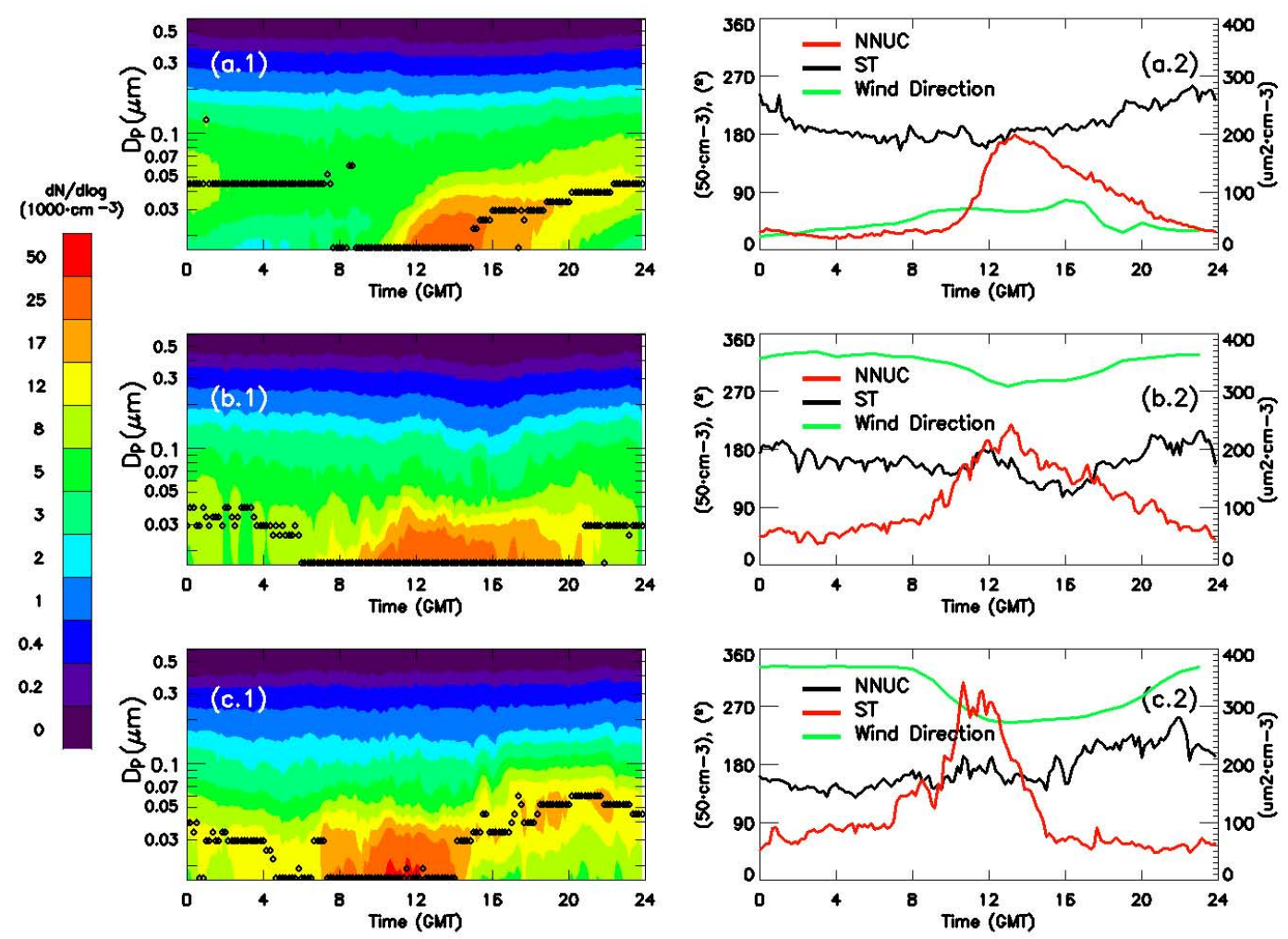

Fig. 12. Classification of the new particle formation events depending on wind direction during the hours prior to the nucleation burst particles and the regional or synoptic-scale pattern. (a.1 and a.2) Event $N_{1}$, if the wind was coming from the NE (48 days), (b.1 and b.2) Event $N_{2}^{\mathrm{NB}}$ if the wind was coming from the NW under synoptic-scale pattern (23 days) and (c.1 and c.2) Event $N_{2}^{\mathrm{B}}$ if the wind was blowing from the NW under sea-land breeze pattern (19 days). Mean size distribution, $N_{\mathrm{NUC}}, S_{\mathrm{T}}$ and wind direction are also shown for Events $N_{1}$, $N_{2}^{\mathrm{NB}}$ and $N_{2}^{\mathrm{B}}$.

accumulation modes (Fig. 12a.1). Particle nucleation and growth rates of the new particle formation events were calculated using the method described by Birmili et al. (2003) and based on their mean size distribution (Fig. 12a.1). The particle nucleation rate was determined by dividing the observed increase in particle concentration between $14-30 \mathrm{~nm}$, by the elapsed time, and a mean value of $0.74 \mathrm{~cm}^{-3} \mathrm{~s}^{-1}$ was obtained. The growth rate was calculated as $1.96 \mathrm{~nm} \mathrm{~h}^{-1}$ from a linear regression analysis of the mode diameter within [14- $\left.D_{\max }\right]$ versus time, where $D_{\max }$ is defined as the maximum of mode diameter. A mean total duration of $9.25 \mathrm{~h}$ (starting at 10:55 GMT and ending at 20:10 GMT) was determined. During Events $N_{1}$, an increase of the mean $S_{\mathrm{T}}$ from $180 \mu \mathrm{m}^{2} \mathrm{~cm}^{-3}$ to $222 \mu \mathrm{m}^{2} \mathrm{~cm}^{-3}$ and a fast increase and later decrease of $N_{\mathrm{NUC}}$ with a maximum of $9890 \mathrm{~cm}^{-3}$ around midday were observed (Fig. 12a.2).

To provide some information on the influence of air mass source region on Events $N_{1}$, the clustering classification introduced in Sect. 3.5 is now constrained to those days in which Events $N_{1}$ were observed. The air mass observed over El Arenosillo at 06:00 GMT, just prior to the onset of the event, was selected as being representative of each of the 48 days with Event $N_{1}$ (Fig. 6), and the event frequency for each air mass types was calculated. It is evident that the Event $N_{1}$ frequency is strongly linked to the air mass origin. Marine north-westerly aerosol from Atlantic and Arctic Oceans (clusters 3 and 6) had the highest probability to lead to an Event $N_{1}$ with $42 \%$ ( $21 \%$ for each one). Lower probabilities were found in the desert dust (cluster 1) with $10 \%$, westerly marine flows (cluster 2 and 5) with $7 \%$ and $16 \%$, respectively, and continental air masses (clusters 4 and 7) with $9 \%$ and $16 \%$, respectively. These observations will be analysed in detail below in Sect. 3.7.3.

The daily mean cycles of particle concentration during NB days and Events $N_{1}$ were compared. As shown in Sect. 3.6, the maximum concentrations for NB days were due to the occurrence of episodes similar to Events $N_{1}$, but with less efficient nucleation processes. The maximum $N_{\mathrm{NUC}}$ for Events $N_{1}$ and NB days were, therefore, $9000 \mathrm{~cm}^{-3}$ (Fig. 12a.2) and $3450 \mathrm{~cm}^{-3}$ (Fig. 11b.1), respectively. The different intensities of the nucleation events at El Arenosillo will allow us to analyse such episodes in more detail in the future. 


\subsubsection{Events $\mathrm{N}_{2}$}

Events $N_{2}$ were classified into two categories: (1) events under the influence of sea-land breeze recirculation (19 days) and (2) events with a synoptic-scale pattern (23 days). According to this segregation, Fig. $12 \mathrm{~b}$ and $12 \mathrm{c}$ show the mean diurnal variation of the particle number size distribution, $N_{\mathrm{NUC}}$ and $S_{\mathrm{T}}$, as well as the wind direction for the 23 days under breeze (identified as Events $N_{2}^{\mathrm{B}}$ ), and for 19 days under non-breeze (identified as Events $N_{2}^{\mathrm{NB}}$ ), respectively.

Events $N_{2}^{\mathrm{B}}$ and $N_{2}^{\mathrm{NB}}$ can be explained as a secondary particle formation which was produced by emissions from the industrial areas situated around Huelva city, located at $35 \mathrm{~km}$ north-west from El Arenosillo (Fig. 1). Because of the wind direction, the anthropogenic pollution with a continuous high level of precursor gases caused an increase in the concentration for nucleation mode aerosol over the sampling site during periods between two and eight hours.

To compare the mean daily particle size distributions for Events $N_{2}^{\mathrm{B}}$ and $N_{2}^{\mathrm{NB}}$, shown in Fig. $12 \mathrm{~b} .1$ and 12c.1, respectively, the particle growth in the afternoon has been analysed. During Events $N_{2}^{\mathrm{B}}$ (Fig. 12c.1), nucleation mode particles from the industrial area were arriving at El Arenosillo; these particles had been grown by condensation and coagulation and were measured again in the evening in the Aitken and accumulation modes, due to the recirculation of the air mass. By contrast, during Events $N_{2}^{\mathrm{NB}}$, the wind direction was almost constant (Fig. 12b.1) and particles at El Arenosillo were always coming directly from the industrial area. No particle growth was observed in the evening and the particle diameter remained constant (Fig. 12b.1).

Events $N_{2}$ were also studied in terms of the airflow patterns, using a similar methodology as that for Events $N_{1}$. During Events $N_{2}^{\mathrm{NB}}$, marine north-westerly aerosols, from the Atlantic and Arctic Oceans (clusters 3 and 6), had event frequencies of $17 \%$ and $31 \%$, respectively. Maritime westerly flow pathways from the Atlantic Ocean (clusters 2 and 5) had event frequencies of $22 \%$ and $17 \%$, respectively. The lowest event frequencies were observed for continental (clusters 4 and 7) with $9 \%$ and $0 \%$, respectively, and desert dust aerosol (cluster 1) with $4 \%$. Based on the analysis of Events $N_{2}^{\mathrm{B}}$ it can be concluded that maritime westerly flows (clusters 2 and 5) caused the highest event frequency with $32 \%$ for each cluster, followed by maritime north-westerly flows (clusters 3 and 6) with $10 \%$ and $16 \%$, respectively. The lowest frequency was observed for both desert dust (cluster 1) with $5 \%$ and continental (clusters 4 and 7 ) with $0 \%$ and $5 \%$.

\subsubsection{Comparison between Events $N_{1}$ and $N_{2}$}

To gain insight into the variations of particle number size distribution, the median size distributions for Events $N_{1}, N_{2}^{\mathrm{B}}$ and $N_{2}^{\mathrm{NB}}$ were evaluated and fitted using a multiple lognormal function. In Table 6 , the modal parameters are shown, indicating that while a bi-modal fit was used to determine the size distribution function for Events $N_{2}^{\mathrm{NB}}$ and $N_{2}^{\mathrm{B}}$, Event $N_{1}$ required a tri-modal fit. The additional mode fit was observed within the accumulation size range and was related to the influence of continental and desert dust air masses on Events $N_{1}$. On the other hand, Mode- 1 reached higher concentrations during Events $N_{2}^{\mathrm{NB}}$ and $N_{2}^{\mathrm{B}}$ than during Event $N_{1}$. This could be related to the particle growth observed during Events $N_{1}$ ("banana shape") which led to a lower mean daily concentration of $N_{\mathrm{NUC}}$ and, thus, a lower particle concentration in Mode-1. The difference between the growth observed in the beginning of Events $N_{1}$ and $N_{2}$ may be due to characteristics of the source region. During an Event $N_{1}$, the aerosols arrived from a large area and grew during transport. However, in the case of Events $N_{2}$, the source is considered as a point of emission, thus, all particles started out with similar diameters at the same time and arrived at El Arenosillo having grown to a similar size.

If $N_{1}$ and $N_{2}$ event frequencies by means of air masses histories are analysed together, it is concluded that in general, higher event frequencies were observed under conditions of marine air mass which showed smaller values for concentration in the accumulation mode and for aerosol surface area (Fig. 10a). This dependence on the pre-existing aerosol surface is corroborated by previous studies, in regional background sites (Birmili and Wiedensohler, 2000; Rodríguez et al., 2005; Shen et al., 2011), in urban areas (Wehner et al., 2008) and at high latitude sites (Kivekäs et al., 2009; Sellegri et al., 2010).

Within this general behaviour, it is noteworthy that there are two exceptions at El Arenosillo: the low event frequency of Events $N_{1}$ during westerly flows (cluster 2) and a high frequency in continental air masses (cluster 7) (Fig. 8). On days with nucleation events, the air masses came from the south of Greenland and entered the Iberian Peninsula from the north. Because of that, the cluster algorithm grouped them within cluster 7. Thus, air masses were over the Atlantic sea for some time, and $N_{\mathrm{ACC}}$ was lower than in other size distributions also classified by cluster 7 , which showed once more a dependence of the event frequency on the preexisting aerosol surface. The low event frequency of Events $N_{1}$ in air masses classified as cluster 2 is difficult to explain. These behaviours observed in clusters 7 and 2 will be analysed in the future.

The number of days with nucleating events showed a clear impact on the monthly mean concentrations during Period A (Fig. 3), with higher $N_{\mathrm{NUC}}$ in April than in January, reflecting the even frequencies during these periods (33\% vs. $6 \%$, respectively). The greater concentration of nucleation mode particles during April shows once more the greater probability of homogenous nucleation events in the absence of abundant pre-existing aerosols. 
Table 6. Median number size distribution log-normal parameters of Events $N_{1}, N_{2}-$ Breeze and $N_{2}-$ Non Breeze. The $D_{\mathrm{g}, i}, N_{i}$ and $\sigma_{\mathrm{I}}$ represent the geometric diameter, median number concentration and geometric standard deviation, respectively. The correlation coefficient $(R)$ between observed and fitted size distribution is also shown. ${ }^{*}$ The median and mean total number concentrations $\left(N_{\mathrm{T}, \text { median }}\right.$ and $\left.N_{\mathrm{T}, \text { mean }}\right)$ are calculated from the measured values instead of the fitted ones.

\begin{tabular}{lrrrrrrrrrrrrr}
\hline & Mode-1 & \multicolumn{3}{c}{ Mode-2 } & & Mode-3 & & Median & Mean \\
\hline & $\begin{array}{r}D_{\mathrm{g}, 1} \\
\mathrm{~nm}\end{array}$ & $\begin{array}{r}N_{1} \\
\mathrm{~cm}^{-3}\end{array}$ & $\begin{array}{r}\sigma_{\mathrm{g}, 1} \\
\end{array}$ & $\begin{array}{r}D_{\mathrm{g}, 2} \\
\mathrm{~nm}\end{array}$ & $\begin{array}{r}N_{2} \\
\mathrm{~cm}^{-3}\end{array}$ & $\begin{array}{r}\sigma_{\mathrm{g}, 2} \\
D_{\mathrm{g}, 3} \\
\mathrm{~nm}\end{array}$ & $\begin{array}{r}N_{3} \\
\mathrm{~cm}^{-3}\end{array}$ & $\sigma_{\mathrm{g}, 3}$ & $\begin{array}{r}R^{2} \\
{ }^{*} N_{\mathrm{T}, \text { median }} \\
\mathrm{cm}^{-3}\end{array}$ & $\begin{array}{r}N_{\mathrm{T}, \text { mean }} \\
\mathrm{cm}^{-3}\end{array}$ \\
\hline Event $N_{1}$ & 34 & 5030 & 1.73 & 100 & 2390 & 1.80 & 460 & 20 & 1.30 & 0.99 & 7320 & 9370 \\
Event $N_{2}^{\mathrm{B}}$ & 29 & 8640 & 1.71 & 90 & 1900 & 1.96 & - & - & - & 1.00 & 9790 & 12070 \\
Event $N_{2}^{\mathrm{NB}}$ & 20 & 11200 & 2.09 & 81 & 2500 & 2.01 & - & - & - & 0.99 & 9160 & 10290 \\
\hline
\end{tabular}

\section{Summary and conclusions}

The first description of a long-term monitoring of the submicron particle size distribution at mid-latitudes on the Atlantic Ocean coast close to the rural background environment of Doñana National Park was presented in this work. Characterisation of primary particle emissions, secondary particle formation, changes of meteorology and long-term transport were performed in order to interpret the particle size distribution within the size range (14-673) nm during the two-year period (August 2004-July 2006).

The sub-micron particle size distribution observed was related to different sources and atmospheric patterns (regional and synoptic-scale processes). The sampling area was influenced by breeze circulation, which is known to be a process that accumulates particles over coastal areas. Long range transport sources, which are represented by synoptic-scale processes, were dominated by desert dust, marine and continental aerosol. The particle concentration observed during the synoptic and regional-scale patterns were impacted by new particle formation events, which were classified with regard to the particle sources. In this study, SMPS data have been analysed under three different aspects, i.e., in terms of the atmospheric flows using HYSPLIT back-trajectories, mesoscale winds and nucleation events.

In this context, the mean total concentration $\left(N_{\mathrm{T}}\right)$ over the two-year period was $8660 \mathrm{~cm}^{-3}$ and the mean modal concentrations were $2830 \mathrm{~cm}^{-3}, 4410 \mathrm{~cm}^{-3}$ and $1720 \mathrm{~cm}^{-3}$ for the nucleation $\left(N_{\mathrm{NUC}}\right)$, Aitken $\left(N_{\mathrm{AIT}}\right)$ and accumulation $\left(N_{\mathrm{ACC}}\right)$ modes, respectively. The mean total particle surface area $\left(S_{\mathrm{T}}\right)$ and volume $\left(V_{\mathrm{T}}\right)$ concentrations were $245 \mu \mathrm{m}^{2} \mathrm{~cm}^{-3}$ and $9 \mu \mathrm{m}^{3} \mathrm{~cm}^{-3}$, respectively. Comparing the total and modal mean concentrations reported in this study with other sites at similar latitudes, particle concentrations are more similar to those found at stations of rural areas located in Central Europe, than at coastal rural sites.

An independence of the $N_{\mathrm{T}}$ with the season was observed. This absence of seasonality resulted from a clear inverse variation between $N_{\mathrm{NUC}}$ and $N_{\mathrm{ACC}}$, which was related to the incidence or the non-incidence of desert dust and continental air masses over El Arenosillo. These air masses were associated with high values of $N_{\mathrm{ACC}}$ and with large surface area concentrations which favoured the condensation of gases onto pre-existing particles and suppressed the new particle formation (decreasing $N_{\mathrm{NUC}}$ ). The total number concentration showed a clear diurnal variation with a maximum around noon, which was governed by $N_{\mathrm{NUC}}$ and $N_{\mathrm{AIT}}$ during the warm seasons and by $N_{\text {NUC }}$ during cold seasons. The diurnal maximum was attributed to nucleation events from autumn to spring time. During summer time, the diurnal maximum was attributed mainly to the accumulation of particles offshore during sea-land breeze days.

The samples influenced by synoptic-scale patterns were classified by air mass type using a cluster algorithm. The particle size distributions influenced by maritime air masses showed greater particle number concentrations in the nucleation and Aitken modes, whereas the size distributions influenced by desert dust and continental air masses were dominated by the Aitken and accumulation modes. In addition, a striking similarity of the median size distributions at El Arenosillo was found to air masses that originated from Central Europe and the Iberian Peninsula and from the African continent.

Air masses impacted by regional circulation were classified in terms of pure breeze (land flows blowing from the $\mathrm{NE}\left(0^{\circ}-67^{\circ}\right.$ sector)) and non-pure breeze (land flows blowing from the $\mathrm{NW}\left(315^{\circ}-337^{\circ}\right.$ sector $\left.)\right)$. The greatest impact on the particle background levels, next to the change in wind direction from offshore to onshore, was observed with an onshore wind arriving at the coast of El Arenosillo around noon. The effect of the non-pure breeze on particle levels was significantly higher than the effect of the pure breeze. This is related to the impact of the emissions from the industrial area located in the NW sector. It can be considered as an example of how the recirculation of air pollution in coastal places with industrial activities can influence the air quality. On the other hand, for an appropriate interpretation of the particle levels during these regional episodes, synoptic-scale 
patterns should be considered. For example, days under pure breeze were mainly influenced by continental and desert dust air masses and the hourly concentrations for accumulation mode air were higher than for days under non-pure breeze.

New particle formation events were more common during synoptic-scale atmospheric processes. In addition, the number of days with nucleation events showed a clear influence on the monthly mean particle levels, explaining the seasonal and annual behaviour of the particle concentration. Two types of nucleation events $\left(N_{1}\right.$ and $\left.N_{2}\right)$ were identified in terms of the source region. Events $N_{1}$ were observed with the wind from a forest area (Doñana National Park) and Seville City. They were quite homogeneous in a larger-scale air mass and had the typical "banana" shape. Events $N_{2}$ were observed with the wind from the industrial areas near Huelva City. Particles that were transported directly from the point of emission to El Arenosillo were mostly in the nucleation mode size range. Particles of larger diameters were only observed during the breeze circulation and when the condensation and coagulation processes were efficient. The frequency of Events $N_{1}$ and $N_{2}$ was strongly linked to the marine aerosol from the Atlantic and Arctic oceans which might be explained by a lower surface area concentration than that of desert dust and continental aerosol.

Acknowledgements. This work has been supported by the Spanish Ministry for Science and Innovation (MICINN) through projects CLIMARENO - CGL2008-05939-C03-03/CLI and AEROMICROPRO - CGL2010-18782; by the Andalusian Regional Government through project TARTESOS - P10-RNM-6299. The authors would like to express their gratitude to the European Union (6th framework EUSAAR - RII3-CT-2006-026140) for providing technical support and the NOAA Air Resources Laboratory (ARL) for the HYSPLIT back-trajectories. The authors are grateful for the valuable comments by the editor and the reviewers.

Edited by: B. Ervens

\section{References}

Adame, J. A., Lozano, A., Bolívar, J. P., De la Morena, B. A., Contreras, J., and Godoy, F.: Behaviour, distribution and variability of surface ozone at an arid region in the south of Iberian Peninsula (Seville, Spain), Chemosphere, 70, 841-849, 2008.

Adame, A. A., Serrano, E., Bolívar, J. P., and De la Morena, B. A.: On the tropospheric ozone variations in a coastal area of Southwestern Europe under a Mesoscale Circulation, J. Appl. Meteorol. Climatol., 49, 748-759, doi:10.1175/2009JAMC2097.1, 2010a.

Adame, J. A., Bolívar, J. P., and De la Morena, B. A.: Surface ozone measurements in the southwest of the Iberian Peninsula (Huelva, Spain), Environ. Sci. Pollut. Res., 17, 355-368, 2010 b.

Antilla, P., Rissanen, T., Shimmo, M., Kallio, M., Hyötyläinen, T., Kulmala, M., and Riekkola, M.-L.: Organic compounds in atmospheric aerosols from a Finish coniferous forest, Boreal Environ. Res., 10, 371-384, 2005.
Asmi, A., Wiedensohler, A., Laj, P., Fjaeraa, A.-M., Sellegri, K., Birmili, W., Weingartner, E., Baltensperger, U., Zdimal, V., Zikova, N., Putaud, J.-P., Marinoni, A., Tunved, P., Hansson, H.C., Fiebig, M., Kivekäs, N., Lihavainen, H., Asmi, E., Ulevicius, V., Aalto, P. P., Swietlicki, E., Kristensson, A., Mihalopoulos, N., Kalivitis, N., Kalapov, I., Kiss, G., de Leeuw, G., Henzing, B., Harrison, R. M., Beddows, D., O’Dowd, C., Jennings, S. G., Flentje, H., Weinhold, K., Meinhardt, F., Ries, L., and Kulmala, M.: Number size distributions and seasonality of submicron particles in Europe 2008-2009, Atmos. Chem. Phys., 11, 5505-5538, doi:10.5194/acp-11-5505-2011, 2011.

Birmili, W. and Wiedensohler, A.: New particle formation in the continental boundary layer: meteorological and gas phase parameter influence, Geophys. Res. Lett., 27, 3325-3328, 2000.

Birmili, W., Stratmann, F., Wiedensohler, A., Covert, D., Russell, L. M., and Berg, O.: Determination of differential mobility analyser transfer functions using identical instruments in series, Aerosol Sci. Tech., 27, 215-223, 1997.

Birmili, W., Wiedensohler, A., Heintzenberg, J., and Lehmann, K.: Atmospheric particle number size distribution in central Europe: statistical relations to air masses and meteorology, J. Geophys. Res., 106, 32005-32018, 2001.

Birmili, W., Berresheim, H., Plass-Dülmer, C., Elste, T., Gilge, S., Wiedensohler, A., and Uhrner, U.: The Hohenpeissenberg aerosol formation experiment (HAFEX): a longterm study including size-resolved aerosol, $\mathrm{H}_{2} \mathrm{SO}_{4}, \mathrm{OH}$, and monoterpenes measurements, Atmos. Chem. Phys., 3, 361-376, doi:10.5194/acp-3-361-2003, 2003.

Boy, M. and Kulmala, M.: Nucleation events in the continental boundary layer: Influence of physical and meteorological parameters, Atmos. Chem. Phys., 2, 1-16, doi:10.5194/acp-2-1-2002, 2002.

Cachorro, V. E., Toledano, C., Prats, N., Sorribas, M., Mogo, S., Berjón, A., Torres, B., Rodrigo, R., De Frutos, A. M., De la Rosa, J., and De la Morena, B. A.: The strongest desert dust intrusion mixed with smoke over the Iberian Peninsula registered with sun-photometry, J. Geophys. Res., 113, D14S04, doi:10.1029/2007JD009582, 2008.

Charlson, R. J. and Wigley, T. M. L.: Sulphate aerosol and climate change, Sci. Am., 270, 48-57, 1994.

Charlson, R. J., Lovelock, J. E., Andreae, M. O., and Warren, S. G.: Oceanic phytoplankton, atmospheric sulphur, cloud albedo and climate, Nature, 326, 655-661, 1987.

Córdoba-Jabonero, C., Sorribas, M., Guerrero-Rascado, J. L., Adame, J. A., Hernández, Y., Lyamani, H., Cachorro, V., Gil, M., Alados-Arboledas, L., Cuevas, E., and de la Morena, B. Synergetic monitoring of Saharan dust plumes and potential impact on surface: a case study of dust transport from Canary Islands to Iberian Peninsula, Atmos. Chem. Phys., 11, 3067-3091, doi:10.5194/acp-11-3067-2011, 2011.

Draxler, R. R and Hess, G. D.: An overview of the HYSPLIT_4 modeling system for trajectories, dispersion, and deposition. Aust. Meteor. Mag., 47, 295-308, 1998.

Gangoiti, G., Alonso, L., Navazo, M., Albizuri, A., Perez-Landa, G., Matabuena, M., Valdenebro, V., Maruri, M., García, J. A., and Millán, M. M.: Regional transport of pollutants over the Bay of Biscay. Analysis of an ozone episode under a blocking anticyclone in west-central Europe, Atmos. Environ., 36, 1349-1361, 2002. 
Hamed, A., Joutsensaari, J., Mikkonen, S., Sogacheva, L., Dal Maso, M., Kulmala, M., Cavalli, F., Fuzzi, S., Facchini, M. C., Decesari, S., Mircea, M., Lehtinen, K. E. J., and Laaksonen, A.: Nucleation and growth of new particles in Po Valley, Italy, Atmos. Chem. Phys., 7, 355-376, doi:10.5194/acp-7-355-2007, 2007.

Heintzenberg, J., Covert, D. C., and Dingenen, R. V: Size distribution and chemical composition of marine aerosols: a compilation and review, Tellus, 52B, 1104-1122, 2000.

Hsu, S. A.: Coastal meteorology, Academic Press, Inc, ISBN 0-12357955-4, 260 pp., 1988.

Hondula, D. M., Sitka, L., Davis, R. E., Knight, D. B., Gawtry, S. D., Deaton, M. L., Lee, T. R., Normile, C. P., and Stenger, P. J.: A back-trajectory and air mass climatology for the Northern Shenandoah Valley, USA. Int. J. Climatol., 30, 569-581, doi:10.1002/joc.1896, 2009.

Ieda, T., Kitamori, Y., Mochida, M., Hirata, R., Hirano, T., Inulai, K., Fijinuma, Y., and Kawamura, K.: Diurnal variations and vertical gradients of biogenic volatile and semi-volatile organic compounds at the Tomakomai larch forest stations in Japan, Tellus, 59B, 177-186, 2006.

Jeong, C.-H., Evans, G. J., McGuire, M. L., Chang, R. Y.-W., Abbatt, J. P. D., Zeromskiene, K., Mozurkewich, M., Li, S.-M., and Leaitch, W. R.: Particle formation and growth at five rural and urban sites, Atmos. Chem. Phys., 10, 7979-7995, doi:10.5194/acp10-7979-2010, 2010.

Kivekäs, N., Sun, J., Zhan, M., Kerminen, V.-M., Hyvärinen, A., Komppula, M., Viisanen, Y., Hong, N., Zhang, Y., Kulmala, M., Zhang, X.-C., Deli-Geer, and Lihavainen, H.: Long term particle size distribution measurements at Mount Waliguan, a highaltitude site in inland China, Atmos. Chem. Phys., 9, 5461-5474, doi:10.5194/acp-9-5461-2009, 2009.

Kleefeld, C., O’Dowd, C. D., O’Reilly, S., Jennings, S. G., Aalto, P., Becker, E., Kunz, G., and De Leeuw, G.: Relative contribution of submicron and supermicron particles to aerosol light scattering in the marine boundary layer, J. Geophys., Res., 107, 8103, doi:10.1029/2000JD000262, 2002.

Knutson, E. O. and Whitby, K. T.: Aerosol classification by Electric Mobility: Apparatus, Theory and Applications, J. Aerosol Sci., 6, 443-451, 1975.

Kohornen, P., Kulmala, M., Laaksonen, A., Viisanen, Y., Mcraw, R., and Seinfeld, J. H.: Ternary Nucleation of $\mathrm{H}_{2} \mathrm{SO}_{4}, \mathrm{NH}_{3}$ and $\mathrm{H}_{2} \mathrm{O}$ in the Atmosphere, J. Geophys. Res., 104, 26349-26353, 1999.

Kulmala, M., Laaksonen, A., and Pirjola, L: Parameterizations for sulphuric acid/water nucleation rates, J. Geophys. Res., 103, 8301-8307, 1998.

Kulmala, M., Hämeri, K., Aalto, P. P., Mäkelä, J. M., Pirjola, L., Douglas, N., Buzorius, G., Rannik, Ü, Dal Maso, M., Seidl, W., Hoffman, T., Janson, R., Hansson, H.-C., Viisanen, Y., Laaksonen, A., and O'Dowd, C. D.: Overview of the international project on biogenic aerosol formation in the boreal forest (BIOFOR), Tellus, 53B, 324-343, 2001.

Kulmala, M., Vehkamäki, H., Petäjä, T., Dal Maso, M., Lauri, A., Kerminen, V.-M., Birmili, W., and MecMurry, P. H.: Formation and growth rates of ultrafine atmospheric particles: a review of observations, Aerosol Sci. Tech., 35, 143-176, 2004.
Kulmala, M., Lehtinen, K. E. J., and Laaksonen, A.: Cluster activation theory as an explanation of the linear dependence between formation rate of $3 \mathrm{~nm}$ particles and sulphuric acid concentration, Atmos. Chem. Phys., 6, 787-793, doi:10.5194/acp-6-787-2006, 2006.

Lozano, R. L., Hernández-Ceballos, M. A., Adame, J. A., CasasRuíz, M., Sorribas, M., San Miguel, E. G., and Bolívar, J. P: Radioactive impact of Fukushima accident on the Iberian Peninsula: Evolution and plume previous pathway, Environmental International, 37, 1259-1264, 2011.

Ma, Y. and Lyons, T. L.: Recirculation of coastal urban air pollution under a synoptic scale thermal trough in Perth, Western Australia, Atmos. Environ., 37, 443-454, 2003.

Mahajan, A. S., Sorribas, M., Gómez Martn, J. C., MacDonald, S. M., Gil, M., Plane, J. M. C., and Saiz-Lopez, A.: Concurrent observations of atomic iodine, molecular iodine and ultrafine particles in a coastal environment, Atmos. Chem. Phys., 11, 2545-2555, doi:10.5194/acp-11-2545-2011, 2011.

Manktelow, P. T., Carslaw, K. S., Mann, G. W., and Spracklen, D. V.: The impact of dust on sulfate aerosol, $\mathrm{CN}$ and $\mathrm{CCN}$ during an East Asian dust storm, Atmos. Chem. Phys., 10, 365-382, doi:10.5194/acp-10-365-2010, 2010.

Mogo, S., Cachorro, V. E., Sorribas, M., De Frutos, A. M., and Fernández, R.: Measurements of continuous spectra of atmospheric absorption coefficients from UV to NIR via optical method, Geophys. Res. Lett., 32, L13811, doi:10.1029/2005GL022938, 2005.

Mogo, S., Cachorro, V. E., De Frutos, A. M., De la Rosa, J., and Sorribas, M.: Comparing surface measurement of black carbon and columnar AERONET inferred contents during the "El Arenosillo 2004 summer campaign”, Opt. Pura Apl., 43, 49-55, 2010.

Pey, J., Querol, X., De la Rosa, J., González-Castanedo, Y., Alastuey, A., Gangoiti, G., Sánchez de la Campa, A., AladosAlboledas, L., Sorribas, M., Pio, C., Cachorro, V., Piñeiro, M., López-Mahia, P., and García-Gacio, D.: Characterization of a long range transport pollution episode affecting PM in SW Spain, J. Environ. Monitor., 10, 1158-1171, doi:10.1039/b809001g, 2008.

Prats, N., Cachorro, V. E., Sorribas, M., Mogo, S., Berjón, A., Toledano, C., De Frutos, A. M., De la Rosa, J., Laulainen, N., and De la Morena, B. A.: Columnar aerosol optical properties during El Arenosillo 2004 summer campaign, Atmos. Environ., 42, 2643-2653, 2008.

Querol, X., Alastuey, A., Rodríguez, S., Viana, M. M., Artíñano, B., Salvador, P., Mantilla, E., García do Santos, S., Fernández Patier, R., De la Rosa, J., Sanchez de la Campa, A., Menéndez, M., and Gil, J. J.: Levels of particulate matter in rural, urban and industrial sites in Spain, Sci. Total Environ., 334-335, 359-376, 2004.

Querol, X., Alastuey, A., Moreno, T., Viana, M. M., Castillo, S., Pey, J., Rodríguez, S., Artiñano, B., Salvador, P., Sánchez, M., García Dos Santos, S., Herce Garraleta, M. D., Fernández-Patier, R., Moreno-Grau, S., Negral, L., Minguillon, M. C., Monfort, E., Sanz, M. J., Palomo-Marín, R., Pinilla-Gil, E., Cuevas, E., De la Rosa, J., and Sánchez de la Campa, A.: Spacial and temporal variations in airborne particulate matter $\left(\mathrm{PM}_{10}\right.$ and $\left.\mathrm{PM}_{2.5}\right)$ across Spain 1999-2005, Atmos. Environ., 42, 3964-3979, 2008. 
Rodríguez, S., Dingenen, R. V., Putaud, J.-P, Santos, S. M.-D., and Roselli, D.: Nucleation and growth of new particles in the rural atmosphere of Northern Italy-relationship to air quality monitoring, Atmos. Environ., 39, 6734-6746, 2005.

Sánchez de la Campa, A. M., Pio, C., De la Rosa, J., Querol, X., Alastuey, A., and González-Castanedo, Y.: Characterization and origin of EC and OC particulate matter near the Doñana National Park (SW Spain), Environ. Res., 109, 671-681, 2009.

Sellegri, K., Laj, P., Venzac, H., Boulon, J., Picard, D., Villani, P., Bonasoni, P., Marinoni, A., Cristofanelli, P., and Vuillermoz, E.: Seasonal variations of aerosol size distributions based on longterm measurements at the high altitude Himalayan site of Nepal Climate Observatory-Pyramid (5079 m), Nepal, Atmos. Chem. Phys., 10, 10679-10690, doi:10.5194/acp-10-10679-2010, 2010.

Shen, X. J., Sun, J. Y., Zhang, Y. M., Wehner, B., Nowak, A., Tuch, T., Zhang, X. C., Wang, T. T., Zhou, H. G., Zhang, X. L., Dong, F., Birmili, W., and Wiedensohler, A.: First longterm study of particle number size distributions and new particle formation events of regional aerosol in the North China Plain, Atmos. Chem. Phys., 11, 1565-1580, doi:10.5194/acp-11-15652011, 2011.

Sheridan, P. J., Delene, D. J., and Ogren, J. A.: Four years of continuous surface aerosol measurements from the Department of Energy's Atmospheric Radiation Measurement Program Southern Great Plains Cloud and Radiation Testbed site, J. Geophys. Res., 106, 20735-20747, 2001.

Solomon, S., Qin, D., Manning, M., Chen, Z., Marquis, M., Averyt, K. B., Tignor, M., and Miller, H. L. (Eds.): Contribution of Working Group I to the Fourth Assessment Report of the Intergovernmental Panel on Climate Change. Cambridge University Press, Cambridge, United Kingdom and New York, NY, USA, 2007.

Spracklen, D. V., Carslaw, K. S., Kulmala, M., Kerminen, V.-M., Sihto, S.-L., Riipinen, I., Merikanto, J., Mann, G. W., Chipperfield, M. P., Wiedensohler, A., Birmili, W., and Lihavainen, H.: Contribution of particle formation to global cloud condendation nuclei concentrations. Geophys. Res., Lett., 35, L06808, doi:10.1029/2007GL033038, 2008.

Spracklen, D. V., Carslaw, K. S., Merikanto, J., Mann, G. W., Reddington, C. L., Pickering, S., Ogren, J. A., Andrews, E., Baltensperger, U., Weingartner, E., Boy, M., Kulmala, M., Laakso, L., Lihavainen, H., Kivekäs, N., Komppula, M., Mihalopoulos, N., Kouvarakis, G., Jennings, S. G., O’Dowd, C., Birmili, W., Wiedensohler, A., Weller, R., Gras, J., Laj, P., Sellegri, K., Bonn, B., Krejci, R., Laaksonen, A., Hamed, A., Minikin, A., Harrison, R. M., Talbot, R., and Sun, J.: Explaining global surface aerosol number concentrations in terms of primary emissions and particle formation, Atmos. Chem. Phys., 10, 4775-4793, doi:10.5194/acp-10-4775-2010, 2010.

Sorribas, M., Cachorro, V. E., Adame, J. A., Wehner, B., Birmili, W., and Widensohler, A.: Submicrometer aerosol size distributions in southwest-ern Spain: relation with meteorological parameters, Proc. 17th Int. Conf. on Nucleation and Atmospheric Aerosols, Galway, Ireland, 829-833, 2007.

Sorribas, M.: Medida y Caracterización del Aerosol Atmosférico en un Ambiente Rural y Costero del Suroeste de Europa, La distribución Numérica de Tamaños en el Rango Sub-micrométrico, (Measurement and characterization of Atmospheric aerosol in a rural and coastal environment, Sub-micron particle number size distribution in Southwestern Europe), Ph. D. thesis, University of Valladolid, Valladolid, Spain, 350 pp., availablee at: http://sites.google.com/site/marsorribas/, 2008.

Su, Y. F., Cheng, Y. S., Newton, G. J., and Yeh, H. C.: Counting efficiency of the TSI Model 3020 Condensation Nucleus Counter, Aerosol Sci. Technol., 12, 1050-1054, 1990.

Takemura, T., Nakajima, T., Dubovic, O., Holben, B. N., and Kinne, S.: Single-scattering albedo and radiative forcing of various aerosol species with a global three-dimensional model, J. Climate, 15, 333-352, 2002.

Toledano, C.: Climatología de los aerosoles mediante la caracterización de propiedades ópticas y masas de aire en la estación 'El Arenosillo' de la red AERONET, (Aerosol Climatology through the characterization of optical properties and air masses at El Arenosillo station of the AERONET network), Ph. D thesis, University of Valladolid, Valladolid, Spain, 239 pp., 2005.

Toledano, C., Cachorro, V. E., Berjón, A., De Frutos, A. M., Sorribas, M., De la Morena, B. A., and Goloub, P.: Aerosol optical depth and Ángstrom exponent climatology at El Arenosillo AERONET site (Huelva, Spain), Q. J. Roy. Meteorol., Soc., 133, 795-807, 2007a.

Toledano, C., Cachorro, V. E., De Frutos, A. M., Sorribas, M., Prats, N., and De la Morena, B. A.: Inventory of African desert dust events over the southwestern Iberian Peninsula in 2000-2005 with an AERONET Cimel Sun photometer, J. Geophys. Res., 112, D21201, doi:10.1029/2006JD008307, 2007b.

Toledano, C., Cachorro, V. E., De Frutos, A. M., Torres, B., Berjón, A., Sorribas, M., and Stone, R. S.: Airmass classification and analysis of aerosol types at El Arenosillo (Spain), J. Appl. Meteorol. Clim., 48, 962-981, 2009.

Tunved, P., Hansson, H.-C., Kulmala, M., Aalto, P., Viisanen, Y., Karlsson, H., Kristensson, A., Swietlicki, E., Dal Maso, M., Ström, J., and Komppula, M.: One year boundary layer aerosol size distribution data from five nordic background stations, Atmos. Chem. Phys., 3, 2183-2205, doi:10.5194/acp-3-2183-2003, 2003.

Venzac, H., Sellegri, K., Villani, P., Picard, D., and Laj, P.: Seasonal variation of aerosol size distributions in the free troposphere and residual layer at the puy de Dôme station, France, Atmos. Chem. Phys., 9, 1465-1478, doi:10.5194/acp-9-1465-2009, 2009.

Vergaz, R., Cachorro, V. E., De Frutos A. M., Vilaplana, J. M., and De la Morena, B. A.: Columnar characteristics of aerosols by spectroradiometer measurements in the maritime area of the Cadiz Gulf (Spain), Int. J. Climatol., 25, 1781-1804, 2005.

Van Dingenen, R., Putaud, J.-P., Martins-Dos Santos, S., and Raes, F.: Physical aerosol properties and their relation to air mass origin at Monte Cimone (Italy) during the first MINATROC campaign, Atmos. Chem. Phys., 5, 2203-2226, doi:10.5194/acp-52203-2005, 2005.

Wehner, B., Birmili, W., Ditas, F., Wu, Z., Hu, M., Liu, X., Mao, J., Sugimoto, N., and Widensohler, A.: Relationship between submicrometer particulate air pollution and air mass history in Beijing, China, 2004-2006, Atmos. Phys., 6, 6155-6168, 2008.

Willeke, K. and Baron, P. A.: Aerosol measurements principles, techniques and applications, Van Nostrand Reinhold, New York, USA, 143-195, 1993.

Wright, M. E., Atkinson, D. B., Ziemba, L., Griffin, R., Hiranuma, N., Brooks, S., Lefer, B., Flynn, J., Perna, R., Rappengluck, B., Luke, W., and Kelley, P.: Extensive aerosol optical properties 
and aerosol mass related measurements during TRAMP/TexAQS 2006-Implications for PM compliance and planning, Atmos. Environ, 44, 4035-4044, 2010.
Yum, S. S., Roberts, G., Kim, J. H., Song, K., and Kim, D.: Submicron aerosol size distributions and cloud condensation nuclei concentrations measured at Gosan, Korea, during the Atmospheric Brown Clouds-East Asian Regional Experiment 2005, J. Geophys. Res., 112, D22S32, doi:10.1029/2006JD008212, 2007. 